\title{
Projections of Precipitation and Temperature over the South Asian Countries in CMIP6
}

\author{
Mansour Almazroui $^{1} \oplus \cdot$ Sajjad Saeed $^{1,2,3} \cdot$ Fahad Saeed $^{1,4} \cdot$ M. Nazrul Islam $^{1} \cdot$ Muhammad Ismail $^{1}$
}

Received: 28 December 2019 / Accepted: 11 May 2020 / Published online: 26 May 2020

(c) The Author(s) 2020

\begin{abstract}
The latest Coupled Model Intercomparison Project phase 6 (CMIP6) dataset was analyzed to examine the projected changes in temperature and precipitation over six South Asian countries during the twenty-first century. The CMIP6 model simulations reveal biases in annual mean temperature and precipitation over South Asia in the present climate. In the historical period, the median of the CMIP6 model ensemble systematically underestimates the annual mean temperature for all the South Asian countries, while a mixed behavior is shown in the case of precipitation. In the future climate, the CMIP6 models display higher sensitivity to greenhouse gas emissions over South Asia compared with the CMIP5 models. The multimodel ensemble from 27 CMIP6 models projects a continuous increase in the annual mean temperature over South Asia during the twenty-first century under three future scenarios. The projected temperature shows a large increase (over $6{ }^{\circ} \mathrm{C}$ under SSP5-8.5 scenario) over the northwestern parts of South Asia, comprising the complex Karakorum and Himalayan mountain ranges. Any large increase in the mean temperature over this region will most likely result in a faster rate of glacier melting. By the end of the twenty-first century, the annual mean temperature (uncertainty range) over South Asia is projected to increase by $1.2(0.7-2.1){ }^{\circ} \mathrm{C}, 2.1(1.5-3.3){ }^{\circ} \mathrm{C}$, and $4.3(3.2-6.6)^{\circ} \mathrm{C}$ under the SSP1-2.6, SSP2-4.5, and SSP5-8.5 scenarios, respectively, relative to the present (1995-2014) climate. The warming over South Asia is also continuous on the seasonal time scale. The CMIP6 models projected higher warming in the winter season than in the summer over South Asia, which if verified will have repercussions for snow/ice accumulations as well as winter cropping patterns. The annual mean precipitation is also projected to increase over South Asia during the twenty-first century under all scenarios. The rate of change in the projected annual mean precipitation varies considerably between the South Asian countries. By the end of the twenty-first century, the country-averaged annual mean precipitation (uncertainty range) is projected to increase by 17.1 (2.2-49.1)\% in Bangladesh, 18.9 (-4.9 to 72)\% in Bhutan, 27.3 (5.3-160.5)\% in India, 19.5 (-5.9 to 95.6)\% in Nepal, 26.4 (6.4-159.7)\% in Pakistan, and 25.1 ( -8.5 to 61.0$) \%$ in Sri Lanka under the SSP5-8.5 scenario. The seasonal precipitation projections also shows large variability. The projected winter precipitation reveals a robust increase over the western Himalayas, with a corresponding decrease over the eastern Himalayas. On the other hand, the summer precipitation shows a robust increase over most of the South Asia region, with the largest increase over the arid region of southern Pakistan and adjacent areas of India, under the high-emission scenario. The results presented in this study give detailed insights into CMIP6 model performance over the South Asia region, which could be extended further to develop adaptation strategies, and may act as a guideline document for climate change related policymaking in the region.
\end{abstract}

Keywords Precipitation $\cdot$ Temperature $\cdot$ Future changes $\cdot$ CMIP6 $\cdot$ South Asia

Electronic supplementary material The online version of this article (https://doi.org/10.1007/s41748-020-00157-7) contains supplementary material, which is available to authorized users.

Mansour Almazroui

mansour@kau.edu.sa

1 Center of Excellence for Climate Change Research, Department of Meteorology, King Abdulaziz University, Jeddah, Saudi Arabia
2 The Abdus Salam International Center for Theoretical Physics, Trieste, Italy

3 Department of Earth and Environmental Sciences, University of Leuven (KU Leuven), Leuven, Belgium

4 Climate Analytics, Berlin, Germany 


\section{Introduction}

South Asia is among the most vulnerable regions in the world to the impact of climate change (Bandara and Cai 2014). The total population of South Asia is more than 1.8 billion, accounting for approximately one fourth of the world's population. This region is a global hotspot for food insecurity (Lal 2013). Of the one billion food-insecure people in the world, more than $30 \%$ live in South Asia (Sivakumar and Stefanski 2010). It is projected that climate change will affect food security by the middle of the twenty-first century, with the largest number of food-insecure people located in South Asia (IPCC 2014). The economy of South Asian countries depends largely on agriculture, which is linked with monsoon rainfall and winter temperature. More than $80 \%$ of the water in the region comes from the summer monsoon (Goswami 2012), but large areas in the north and northwest also receive winter precipitation (Dimri et al. 2015; Hunt et al. 2018). The major rivers in South Asia are the Ganges, the Indus, and the Brahmaputra. These river systems are fed mainly from glaciers in the Himalayas. The rapid melting of glaciers in the Himalayas and increased variability in the monsoon rainfall and frequency of extremes make the population of South Asia more vulnerable to climate change (Krishnan et al. 2019; Sivakumar and Stefanski 2010). It is therefore important to understand and assess the changes in these patterns over South Asia for better climate policy making in the future.

The climate of South Asia varies widely and is influenced by both tropical and extratropical climatic systems on timescales varying from interannual to decadal and centurial. There are four seasons in this region, namely spring (March through May), summer (June through September), autumn (October through November), and winter (December through February) (Islam et al. 2010). Precipitation falls mainly during three of these seasons, which are pre-monsoon (March through May), monsoon (June through September), and post-monsoon (October through November) (Islam and Uyeda 2007). This region is specifically known for its very strong seasonal reversal of winds during the summer season. During winter, the northwestern parts of South Asia remain under the influence of western disturbances that originate over the Atlantic Ocean and the Mediterranean Sea and pass over South Asia (Dimri et al. 2015; Madhura et al. 2014; Kumar et al. 2015). During summer, the monsoon associated with southwesterly winds dominates the region (Goswami 2012). The South Asian summer monsoon is one of the most complex meteorological systems on Earth, and its realistic representation in climate model simulations continues to present a challenge for the climate modeling community. On different timescales, the South Asian summer monsoon is also influenced by local conditions and by global phenomena such as the El Niño Southern Oscillation
(ENSO), the North Atlantic Oscillation (NAO), the Circumglobal Wave Train (CGT), Indian Ocean Dipole (IOD), the Madden-Julian Oscillation (MJO), and the Arctic Oscillation (AO) (Krishnamurthy and Krishnamurthy 2014; Wu et al. 2012; Mujumdar et al. 2012; Saeed et al. 2011a, b; Boos and Kuang 2010; Saeed et al. 2009; Lu et al. 2006; Goswami et al. 2006; Bhatla et al. 2017; Ashok et al. 2001). Since a large proportion of annual rainwater in the region comes from the summer monsoon (Goswami 2012), most studies have focused on the summer monsoon rainfall and its variability in the present and future climates (Singh et al. 2019; Kitoh 2017; Krishnan et al. 2013; Turner and Annamalai 2012; Annamalai et al. 2007; Kripalani et al. 2003, 2007; Li and Yanai 1996). Future projections reveal enhanced summer monsoon precipitation and rainfall extremes over South Asia (IPCC 2014). Woo et al. (2019), using a high-resolution (40 km) atmospheric general circulation model, projected an increase in summer precipitation over the Indian subcontinent of 7-10\% under the RCP4.5 scenario and 14-18\% under RCP8.5 for the mid to the end of the twenty-first century. By analyzing datasets from 23 CMIP5 models, Srivastava and Delsole (2014) found a robust response of the South Asian summer monsoon precipitation to increasing greenhouse gas concentration during the twentyfirst century. Jayasankar et al. (2015) further analyzed data from 42 CMIP5 models. They found a clear increase in future temperature over India, but diverse changes in the Indian summer monsoon rainfall, with a substantial intermodel spread in the future projections. On the other hand, the future projections show an increase (more than $3{ }^{\circ} \mathrm{C}$ ) in annual mean temperature over South Asia by the end of the twenty-first century under a high-emission scenario (IPCC 2014).

Most of the studies mentioned above focused on the summer climate over South Asia, but to our knowledge, no study has described the projected changes in annual and seasonal mean temperature and precipitation over South Asia as a whole and at the country scale in the region. The present study will fill this gap by analyzing the latest Couple Model Intercomparison Project phase 6 (CMIP6; see Eyring et al. 2015) model simulation dataset over South Asia. The CMIP6 models differ from those of CMIP5 due to a new generation of climate models and a new start year (2015 for CMIP6 vs. 2006 for CMIP5) for the future scenarios, as well as a new set of specifications for concentration, emission, and landuse scenarios (Gidden et al. 2019). It is still not clear how well the new CMIP6 models simulate the climate response to anthropogenic forcing over South Asia. Moreover, there is no study, to our knowledge, that has analyzed the CMIP6 datasets to examine precipitation and temperature changes for South Asia in the twenty-first century. The main aim of this study is to examine the future temperature and precipitation projections over South Asia using the latest CMIP6 dataset. The paper further describes the projected changes 
in mean temperature and precipitation at national, annual, and seasonal scales, in South Asia.

\section{Data and Methodology}

The 27 CMIP6 models analyzed in this study are listed in Table 1. The CMIP6 dataset is obtained from the CMIP6 database website (https://esgf-node.llnl.gov/search/cmip6 ). The CMIP6 dataset is available at different horizontal resolutions as listed in Table 1. Before starting the analysis, all CMIP6 data are regridded from their original spatial resolutions to a common grid with $1^{\circ} \times 1^{\circ}$ resolution. The temperature data are regridded using a bilinear interpolation technique. The bilinear interpolation technique is widely used for regridding climate data (e g. Almazroui et al. 2017a, b; Sharmila et al. 2015; Turner and Annamalai 2012). For discontinuous variables such as precipitation, a conservative regridding method is more desirable (Jones 1999; Saeed et al. 2017). Therefore, in this study, we used a first-order conservative method for regridding precipitation data. We also used the observational Climatic Research Unit (CRU) data (Harris et al. 2014) to examine the temperature and precipitation climatology over South Asia. The CRU data has been widely used by the scientific community to access the performance of global models over different region of the world (e.g. Almazroui et al. 2017a, b; Kamworapan and Surussavadee 2019).

We first examined the performance of CMIP6 models over South Asia in the present climate (1995-2014) against the CRU observations. For this purpose, we computed the temperature and precipitation biases for each country as well as for the whole of South Asia and examined the spread in bias for the 27 CMIP6 models. Along with the base period 1995-2014, the future temperature and precipitation data were analyzed over three distinct time periods: the nearfuture period 2030-2049, mid-future period 2060-2079, and the far-future period 2080-2099. Temperature and precipitation were also analyzed for summer (JJAS) and winter (DJF) seasons. The ensemble from 27 available CMIP6 models

Table 1 List of CMIP6 models used in this study along with horizontal resolution and country of origin

\begin{tabular}{|c|c|c|c|c|c|}
\hline No. & CMIP6 Model Name & Country & $\begin{array}{l}\text { Horizontal resolution (lon. by } \\
\text { lat. in degrees) }\end{array}$ & Variant label & Key references \\
\hline 1. & ACCESS-CM2 & Australia & $1.9^{\circ} \times 1.3^{\circ}$ & rli1p1f1 & Bi et al. (2012) \\
\hline 2. & ACCESS-ESM1-5 & Australia & $1.9^{\circ} \times 1.2^{\circ}$ & r1i1p1f1 & Law et al. (2017) \\
\hline 3. & BCC-CSM2-MR & China & $1.1^{\circ} \times 1.1^{\circ}$ & r1i1p1f1 & Wu et al. (2019) \\
\hline 4. & CAMS-CSM1-0 & China & $1.1^{\circ} \times 1.1^{\circ}$ & r1ilp1f1 & Rong et al. (2019) \\
\hline 5. & CanESM5 & Canada & $2.8^{\circ} \times 2.8^{\circ}$ & r1ilp1f1 & Swart et al. (2019) \\
\hline 6. & CESM2 & USA & $1.3^{\circ} \times 0.9^{\circ}$ & r1ilp1f1 & Lauritzen et al. (2018) \\
\hline 7. & CESM2-WACCM & USA & $1.3^{\circ} \times 0.9^{\circ}$ & r1i1p1f1 & Liu et al. (2019) \\
\hline 8. & CNRM-CM6-1 & France & $1.4^{\circ} \times 1.4^{\circ}$ & r1i1p1f2 & Voldoire et al. (2019) \\
\hline 9. & CNRM-CM6-1-HR & France & $0.5^{\circ} \times 0.5^{\circ}$ & r1ilp1f2 & Voldoire et al. (2019) \\
\hline 10. & CNRM-ESM2-1 & France & $1.4^{\circ} \times 1.4^{\circ}$ & r1i1p1f2 & Séférian et al. (2019) \\
\hline 11. & EC-Earth3 & Europe & $0.7^{\circ} \times 0.7^{\circ}$ & rli1p1f1 & Massonnet et al. (2020) \\
\hline 12. & EC-Earth3-Veg & Europe & $0.7^{\circ} \times 0.7^{\circ}$ & rli1p1f1 & Not available \\
\hline 13. & FGOALS-f3-L & China & $1.3^{\circ} \times 1^{\circ}$ & r1ilp1f1 & He et al. (2019) \\
\hline 14. & FGOALS-g3 & China & $2^{\circ} \times 2.3^{\circ}$ & r1i1p1f1 & Not available \\
\hline 15. & FIO-ESM-2-0 & China & $1.3^{\circ} \times 0.9^{\circ}$ & r1i1p1f1 & Song et al. (2019) \\
\hline 16. & GFDL-ESM4 & USA & $1.3^{\circ} \times 1^{\circ}$ & r1ilp1f1 & Held et al. (2019) \\
\hline 17. & INM-CM4-8 & Russia & $2^{\circ} \times 1.5^{\circ}$ & r1ilp1f1 & Volodin et al. (2018) \\
\hline 18. & INM-CM5-0 & Russia & $2^{\circ} \times 1.5^{\circ}$ & rli1p1f1 & Volodin et al. (2018) \\
\hline 19. & IPSL-CM6A-LR & France & $2.5^{\circ} \times 1.3^{\circ}$ & r1i1p1f1 & Not available \\
\hline 20. & MIROC6 & Japan & $1.4^{\circ} \times 1.4^{\circ}$ & rli1p1f1 & Tatebe et al. (2019) \\
\hline 21. & MIROC-ES2L & Japan & $2.8^{\circ} \times 2.8^{\circ}$ & r1i1p1f2 & Hajima et al. (2019) \\
\hline 22. & MPI-ESM1-2-HR & Germany & $0.9^{\circ} \times 0.9^{\circ}$ & r1i1p1f1 & Gutjahr et al. (2019) \\
\hline 23. & MPI-ESM1-2-LR & Germany & $1.9^{\circ} \times 1.9^{\circ}$ & r1i1p1f1 & Mauritsen et al. (2019) \\
\hline 24. & MRI-ESM2-0 & Japan & $1.1^{\circ} \times 1.1^{\circ}$ & r1i1p1f1 & Yukimoto et al. (2019) \\
\hline 25. & NESM3 & China & $1.9^{\circ} \times 1.9^{\circ}$ & rli1p1f1 & Cao et al. (2018) \\
\hline 26. & NorESM2-LM & Norway & $2.5^{\circ} \times 1.9^{\circ}$ & r1ilp1f1 & Seland et al. (2020, in review) \\
\hline 27. & UKESM1-0-LL & UK & $1.9^{\circ} \times 1.3^{\circ}$ & r1ilp1f2 & Sellar et al. (2019) \\
\hline
\end{tabular}


for the present and future climates, along with the range of signals, was collected for temperature and precipitation analyses under the three new future pathways of societal development, known as Shared Socioeconomic Pathways (SSPs), which are the low-forcing scenario SSP1-2.6, the medium-forcing scenario SSP2-4.5, and the high-forcing scenario SSP5-8.5. The SSPs are based on five narratives that describe different levels of socioeconomic development (Riahi et al. 2017): sustainable development (SSP1), middle-of-the-road development (SSP2), regional rivalry (SSP3), inequality (SSP4), and fossil fuel-driven development (SSP5). Detailed descriptions of the SSPs are available in O'Neill et al. (2016). The SSP1-2.6, SSP2-4.5, and SSP58.5 scenarios used in this study are considered to be representative of low-, medium-, and high-emission scenarios, respectively.

For the future evaluation of temperature and precipitation under the SSPs in the form of spatial plots, two criteria based on the robustness and significance of change were employed. The robustness of the projected signal was based on the agreement between the different model projections on the direction of changes (Solomon et al. 2007). According to Haensler et al. (2013), the change in the projected signal, whether an increase or decrease, is considered to be robust if at least $66 \%$ of the models agree on the direction of change. Meanwhile, the significance of the change signal is measured by employing a two-tailed Student $t$ test based on equal and unequal variance between the future and historical data for each grid box. Equal and unequal variance is determined for each grid box using an $F$ test. To assess the uncertainty associated with the temperature and precipitation projections over South Asia, the $66 \%$ likely range (17th to 83rd percentile) and full rage (results from all models), along with median values, are used. Furthermore, analyses were performed over entire South Asia as well as over the six constituent countries within South Asia. Finally, we examined the difference between CMIP6 and CMIP5 projections (Table S1) to assess the climate response to the anthropogenic forcing in both sets of CMIP model simulations over South Asia.

\section{Results and Discussion}

\subsection{Mean Temperature and Precipitation Climatology over South Asia}

The observed temperature and precipitation climatologies are shown in Fig. 1a, b. The annual mean temperature during the period $1995-2014$ ranges from -6 to $30{ }^{\circ} \mathrm{C}$ over South Asia (Fig. 1a). The lowest values of the annual mean temperature are recorded in the Himalayan region extending from Bhutan to northern Pakistan. The highest annual mean temperature values occurred in southern Pakistan and the adjacent Gujarat and Rajasthan states of Indian, the southern Indian states of Tamil Nadu, Andhra Pradesh, and Telangana, and the southeastern coast, including the Bay of Bengal and Sri Lanka. The South Asia region also experiences the highest mean temperature during the summer season (not shown). The annual mean precipitation varies from 100 to $4000 \mathrm{~mm}$ year $^{-1}$ over South Asia (Fig. 1b). The lowest annual mean precipitation occurs over the arid region of southern Pakistan and adjacent areas of India. High annual mean precipitation occurs over the Western Ghats of India, central and eastern parts of India, Bangladesh, Sri Lanka, and the foothills of the Himalayas extending from Bhutan to Nepal, northwestern India and Pakistan.

Figure 1c, d shows the performance of the CMIP6 models in the simulation of annual mean temperature and precipitation over South Asia in the present climate with reference to the observations. The length of each bar in Fig. 1c, d displays the spread in the temperature and precipitation biases simulated by the CMIP6 models over six South Asian countries separately as well as over the whole South Asia region against CRU observations. Many CMIP6 models underestimate the annual mean temperature over South Asian countries and the whole South Asia region (Fig. 1c). However, some models overestimate the annual mean temperature. The median values also show a general cold bias in annual mean temperature. On the other hand, the annual mean precipitation bias shows large variability over South Asian countries (Fig. 1d). Many of the models simulated wet bias over Bhutan, Nepal, and Pakistan but negative bias over Bangladesh, India, and Sri Lanka. The spread in annual mean precipitation bias is also large over Bhutan, Nepal, and Pakistan. The large spread in temperature and precipitation biases over Nepal, Pakistan, and Bhutan might be associated with the complex topography and lack of observations over this region. Previous studies based on CMIP5 models indicate that the performance of global climate models varies greatly and also depends on the variable under consideration (Kamworapan and Surussavadee 2019; Pathak et al. 2019). In the present analysis, the $66 \%$ likely range of simulated temperature and precipitation biases spans the zero-line for almost all the cases, indicating satisfactory performance of the whole ensemble (Fig. 1c, d).

\subsection{Projected Changes in Annual Mean Temperature}

The spatial distribution of the projected changes in annual mean temperature over South Asia under three different SSPs is shown in Fig. 2. The spatial pattern of projected temperature shows a larger increase in the northern parts of South Asia under all future scenarios. For the near-future period, the annual mean temperature averaged over South Asia is projected to increase by $0.9{ }^{\circ} \mathrm{C}, 0.9^{\circ} \mathrm{C}$, and $1.2{ }^{\circ} \mathrm{C}$ under 

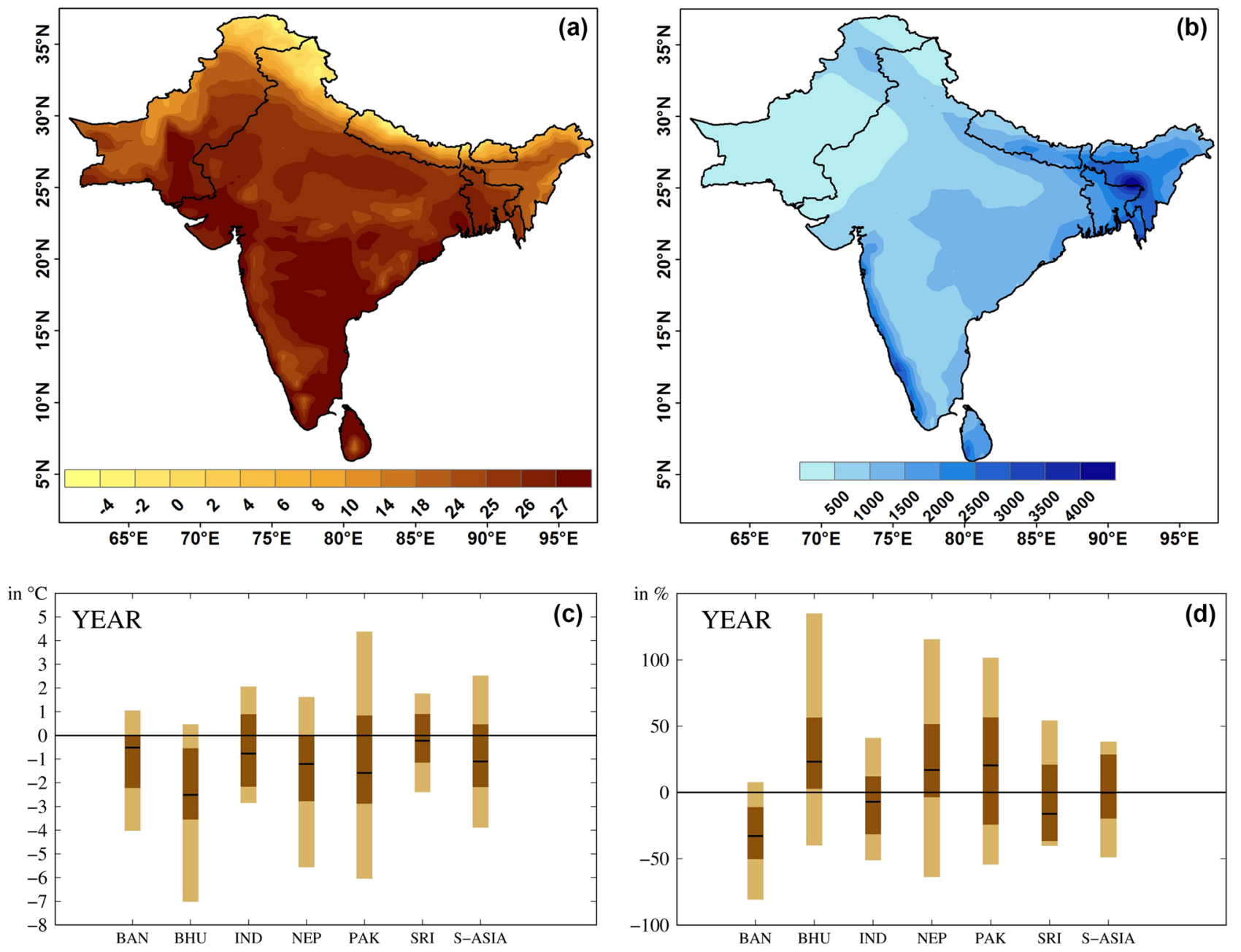

Fig. 1 Observed $\mathbf{a}$ annual mean temperature $\left[{ }^{\circ} \mathbf{C}\right]$ and $\mathbf{b}$ precipitation $\left[\mathrm{mm} \mathrm{year}^{-1}\right]$ climatology over South Asia. The temperature and precipitation climatology are computed using the CRU dataset for the period 1995-2014. The biases in $\mathbf{c}$ temperature $\left[{ }^{\circ} \mathrm{C}\right]$ and $\mathbf{d}$ precipitation [\%] simulated by CMIP6 models over South Asian countries and the whole of South Asia. The bias in the median values is shown by

the black line in each bar. The lower (upper) part of each bar shows the minimum (maximum) bias simulated by the participating CMIP6 models, while the $66 \%$ likely range bias values are shown by dark gray in each bar. The biases are computed for the present climate (1995-2014) with reference to the CRU observational dataset

SSP1-2.6, SSP2-4.5, and SSP5-8.5, respectively. The projected temperature changes are largest over the northwestern part of the South Asian domain, covering the northwestern parts of India and Pakistan. The rest of the South Asia region shows a consistent change in the near-future period under all the three scenarios. The projected annual mean temperature over the region increases as the time progresses. For the mid-future period, the annual mean temperature is projected to increase by $1.2{ }^{\circ} \mathrm{C}, 1.8^{\circ} \mathrm{C}$, and $2.9^{\circ} \mathrm{C}$ under SSP $1-2.6$, SSP2-4.5, and SSP5-8.5, respectively. In the case of the far-future period, the annual mean temperature over South Asia is projected to increase by $1.2{ }^{\circ} \mathrm{C}, 2.1{ }^{\circ} \mathrm{C}$, and $4.3{ }^{\circ} \mathrm{C}$ under SSP1-2.6, SSP2-4.5, and SSP5-8.5, respectively. The distribution of the projected changes in the annual mean temperature over South Asia shows large spatial variability.

The southern coasts of India and Sri Lanka show a small increase, while the northwestern parts of South Asia covering Pakistan show a large increase in the annual mean temperature under all future scenarios considered here. As expected, the large increase in the projected annual mean temperature over South Asia occurs under the high-emission scenario SSP5-8.5. In this case, the largest increase $\left(6^{\circ} \mathrm{C}\right.$ or more) in the future annual mean temperature is projected to occur over Pakistan and adjacent northwestern parts of India and Nepal. This is in agreement with previous findings based on CMIP5 models (Rehman et al. 2018). This region comprises some of the great mountain ranges of the world, i.e., the Hindukush, the Karakoram and western parts of the Himalayas. This region is vulnerable to climate change, and a large increase in temperature will further accelerate the 

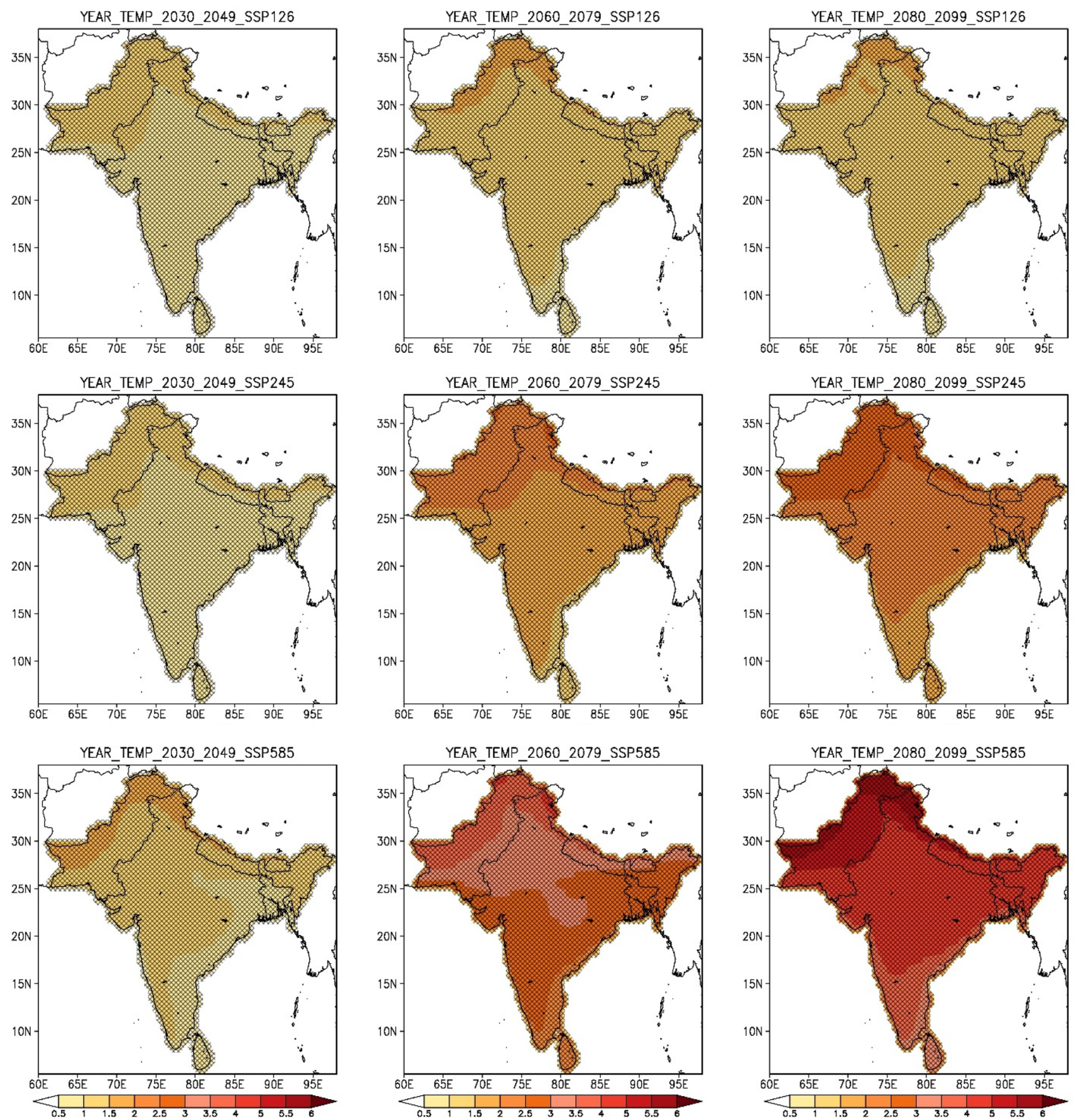

Fig. 2 Spatial distribution of future changes in annual mean temperature over South Asia under three scenarios (SSP1-2.6, SSP2-4.5, SSP5-8.5) for the three future time slices (2030-2049, 2060-2079, and 2080-2099) as compared with the reference period (1995-2014). The backslash and forward slash represent the grid boxes showing

melting of glaciers in this region (Chaturvedi et al. 2014). Previous studies mentioned that even if global warming is kept below $1.5^{\circ} \mathrm{C}$, warming in the Hindukush Himalayan region will likely be at least $0.3{ }^{\circ} \mathrm{C}$ higher, and in the northwest, Himalaya and Karakoram will likely be at least $0.7^{\circ} \mathrm{C}$ significant and robust change, respectively, while hatching represents the grid boxes having both significant and robust change. Significance is defined based on a two-tailed Student $t$ test, while robustness is defined when $66 \%$ of all models project a climate change signal in the same direction

warmer than the global mean (Krishnan et al. 2019). The projected temperature shows a continuous increase over South Asia under three different future scenarios (Fig. 3).

We also examined the changes in the projected temperature for each country in South Asia (Fig. 3). All countries in 

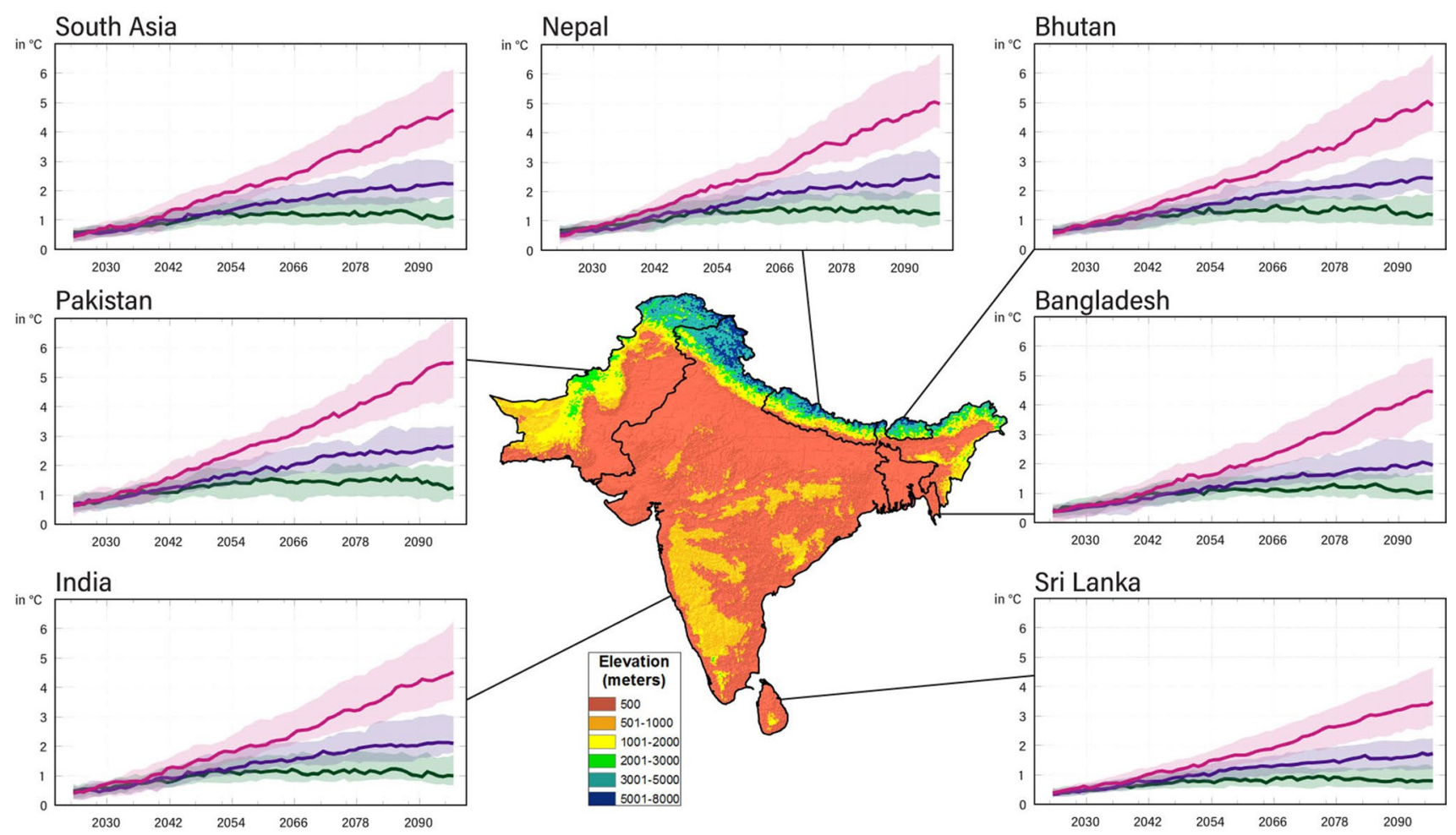

Fig. 3 The evolution of future changes in temperature for the six South Asian countries as well as for entire South Asia during the twenty-first century. The green, purple, and pink curves represent the result for median values for SSP1-2.6, SSP2-4.5, and SSP5-8.5, respectively, and the shaded areas around each curve represent the

South Asia display a continuous increase over time in the annual mean temperature under the three SSP scenarios, at least during the near-future period, as temperatures eventually stabilize under the SSP1-2.6 scenario. The projected changes in the annual mean temperature for three future time slices as compared with the reference period are summarized in Table 2. In the case of the far-future period, the annual mean temperature over Bangladesh is projected to increase by $1.1-4.0{ }^{\circ} \mathrm{C}$. The climate change projections based on a multimodel ensemble from global climate models are missing over Bangladesh. A few previous studies used regional climate models to describe the temperature and precipitation changes over Bangladesh. Caesar et al. (2015) used a 17-member perturbed physics ensemble of projections from a global climate model to drive their regional climate model over South Asia from 1971 to 2099. They found an increase in annual mean temperature from 2.6 to $4.8{ }^{\circ} \mathrm{C}$ by 2100 , relative to the reference period. Alamgir et al. (2019) used eight CMIP5 GCMs to statistically downscale over Bangladesh and reported an increase in temperature by $2.7-4.7^{\circ} \mathrm{C}$ under RCP8.5 at the end of this century. Using 40 CMIP5 GCMs, Rahman and Rob (2019) found a temperature rise of likely range (66\% of the projected changes). The curves are obtained by taking the difference of each future year with respect to the average from the historical period (1995-2014), and then taking the 7-year running average afterward

$2.56{ }^{\circ} \mathrm{C}$ in the capital city, Dhaka, by the end of the twentyfirst century.

The annual mean temperature over Bhutan is projected to increase by $1.3-4.5^{\circ} \mathrm{C}$ by the end of the twenty-first century (Table 2). A recent report on climate projections for Bhutan indicated an increase in the projected temperature by $0.8-3.2{ }^{\circ} \mathrm{C}$ by the end of the twenty-first century. The projected values in our case are larger than those shown in that report for Bhutan. This might be because the above report is based on the analysis of a five-model CMIP5 dataset (NCHM 2019), while in our case the multimodel ensemble is based on a larger number of CMIP6 models.

By the end of the twenty-first century, the annual mean temperature over India is projected to increase by $1.0-4.2{ }^{\circ} \mathrm{C}$ under the three SSP scenarios (Table 2). Chaturvedi et al. (2012), using a multimodel ensemble from 18 CMIP5 datasets, projected mean warming over India under the RCP8.5 scenario to be in the range of $3.3-4.8^{\circ} \mathrm{C}$ by the $2080 \mathrm{~s}$, relative to the preindustrial period. The annual mean temperature over Nepal is projected to increase by $1.3-4.5^{\circ} \mathrm{C}$ in the far-future period under the three SSP scenarios (Table 2). Previous studies also indicated an increase in annual mean 


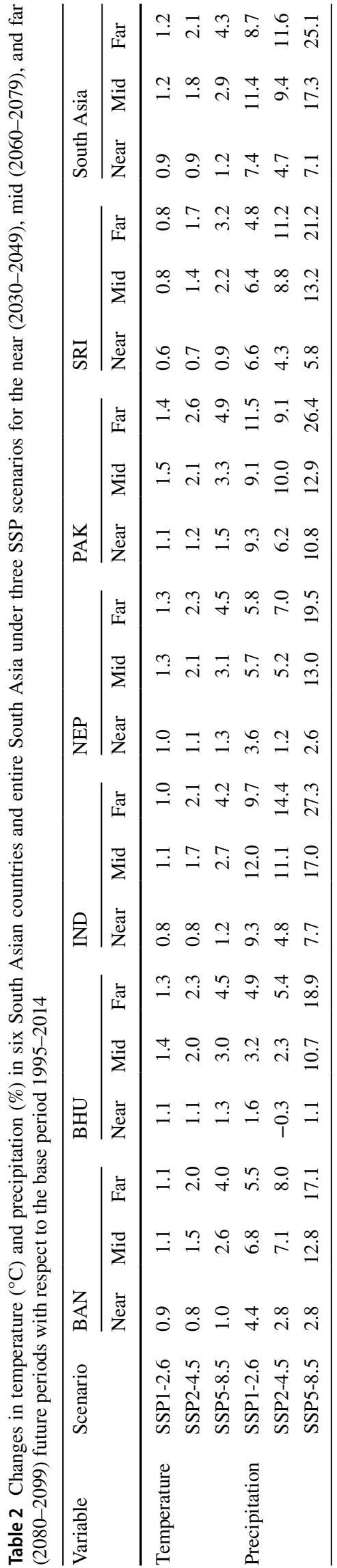

temperature by $1.7-3.6^{\circ} \mathrm{C}$ over Nepal by the end of the twenty-first century (MoFE 2019).

By the end of the twenty-first century, the annual mean temperature over Pakistan under the three SSP scenarios is projected to increase by $1.4-4.9^{\circ} \mathrm{C}$ (Table 2). The projected warming over Pakistan, based on both CMIP5 and CMIP6 datasets, is greater than that over any other area in South Asia (Rehman et al. 2018). The annual mean temperature over Sri Lanka is projected to increase by $0.8-3.2^{\circ} \mathrm{C}$. The rate of increase in annual mean temperature in the CMIP6 projections is smaller over Sri Lanka than over the other South Asian countries. This is in agreement with previous studies for this region (Pattnayak et al. 2017).

\subsection{Projected Changes in Annual Mean Precipitation}

The spatial distribution of projected changes in annual mean precipitation for three future time slices under three SSP emission scenarios is shown in Fig. 4. Most of South Asia shows increased annual mean precipitation in the future climates relative to the reference period. For the near-future period, the projected annual mean precipitation over South Asia shows an increase of 10-20\% under the three SSP scenarios as compared with the present climate (Fig. 4). The projected annual mean precipitation also shows a reduction over southwestern Pakistan and eastern parts of India under SSP2-4.5 (Fig. 4 left panel). For the mid-future period, the projected annual mean precipitation shows an increase of 10-30\% over South Asia (Fig. 4, middle panels). On the other hand, during the far-future period, the annual mean precipitation is projected to increase by $10-20 \%$ under SSP1-2.6, 10-30\% under SSP2-4.5, and $10 \%$ to $>50 \%$ under SSP5-8.5, relative to the present climate (Fig. 4, right panels). Under the high-emission SSP5-8.5 scenario, most of South Asia exhibits a significant and robust increase in annual mean precipitation relative to the present climate. The future projections also indicate a reduction in the annual mean precipitation over southwest Pakistan, but these changes are neither significant nor robust (Fig. 4). Interestingly, in all future scenarios, the projected precipitation increases primarily over the western parts of South Asia. The maximum increase in precipitation is projected over southern Pakistan and adjacent areas of India. This part of South Asia receives very low annual mean precipitation (Fig. 1), so a small increase in the absolute precipitation amount can correspond to a large percentage change over this region.

The projected changes in area-averaged precipitation over time for South Asia and six individual countries are shown in Fig. 5. The projected precipitation shows an increasing trend in all South Asian countries during the twenty-first century, although the curves flatten for the lower-emission scenarios SSP1-2.6 and SSP2-4.5 as the climate stabilizes 

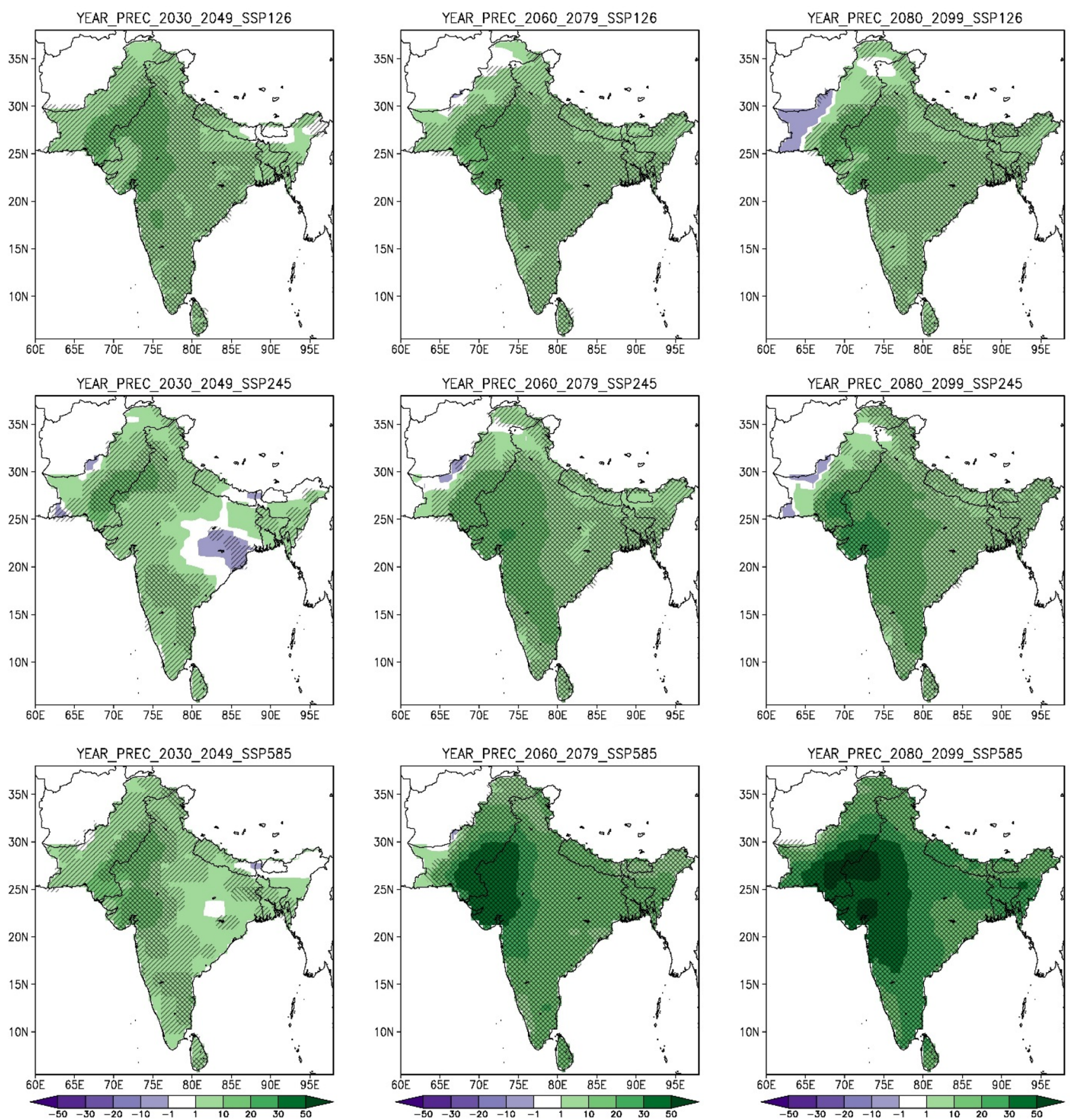

Fig. 4 Same as Fig. 2, except showing the annual mean precipitation change, expressed as a percentage

later in the century. The increasing trend in annual mean precipitation is very clear for the high-emission scenario SPS5-8.5 through the twenty-first century.

The regional and country-averaged precipitation for three future time slices under the three SSPs scenarios are summarized in Table 2. By the end of the twenty-first century, the area-averaged annual mean precipitation over South Asia is projected to increase by $8.7 \%, 11.6 \%$, and 25.1\%, under SSP1-2.6, SSP2-4.5, and SSP5-8.5, respectively (Table 2 ). The projected annual mean precipitation shows a slight variation for the individual countries. The largest increase in annual mean precipitation is projected under SSP5-8.5. In the future, under the three SSP scenarios, the annual mean precipitation is projected to increase by $4.4-17.1 \%$ over Bangladesh (Table 2). Over Bhutan, the annual precipitation is projected to increase by $1.6-18.9 \%$. For India, the annual precipitation is projected to increase by $9.3-27.3 \%$. The annual precipitation 

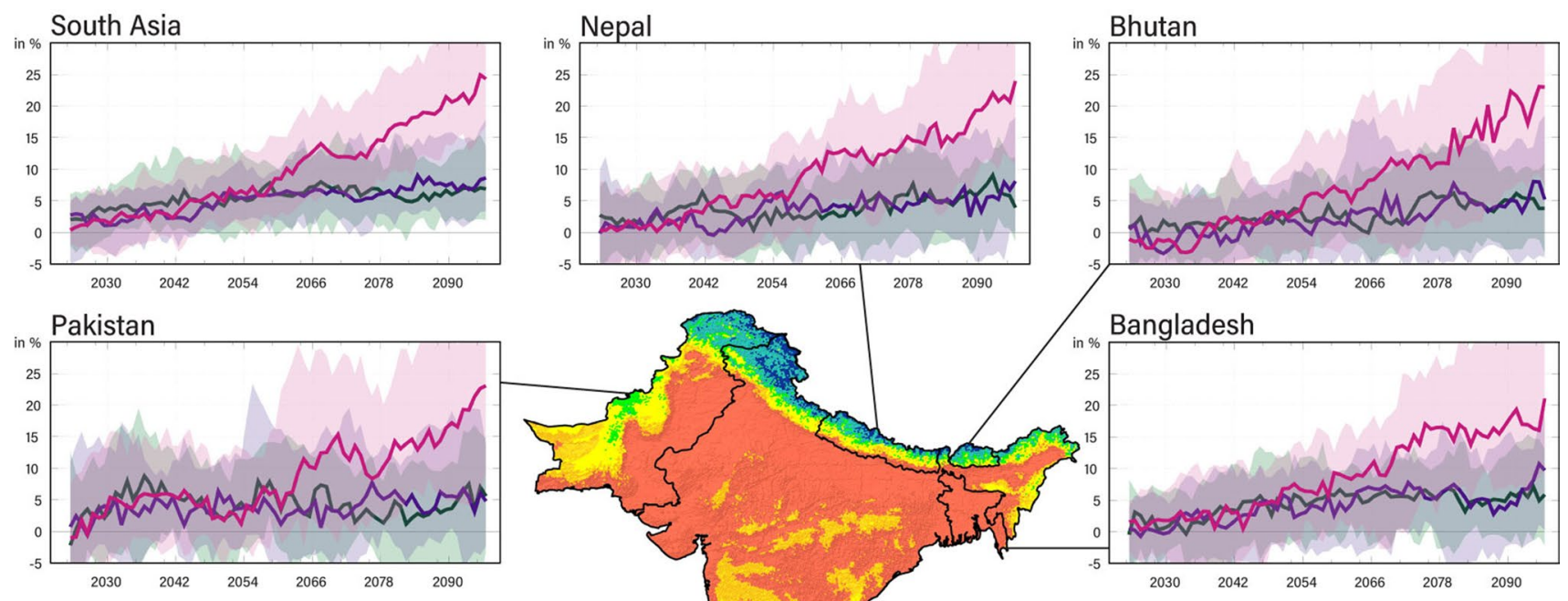

Bangladesh
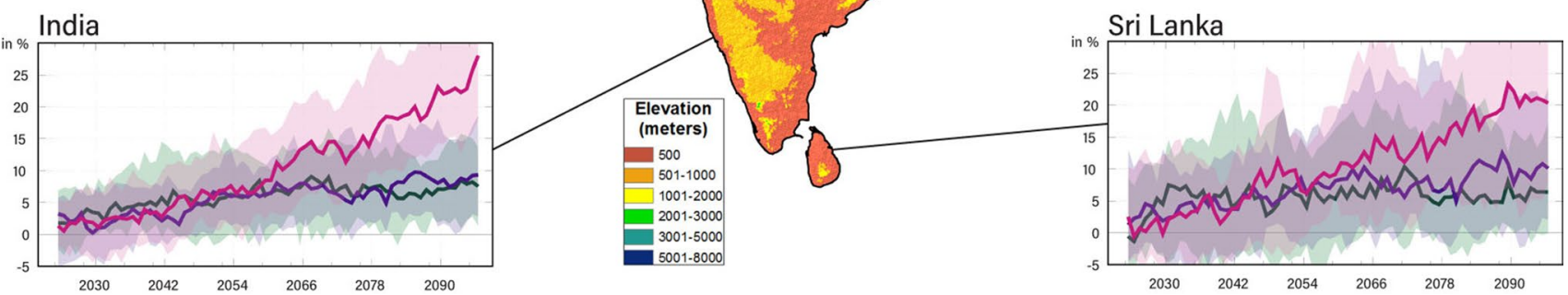

Fig. 5 Same as Fig. 3, except showing future changes in precipitation for the six countries as well as over the whole of South Asia. The green, purple, and pink curves represent the results for median values for SSP1-2.6, SSP2-4.5, and SSP5-8.5, respectively, and the shaded

over Nepal is projected to increase by $3.6-19.5 \%$. For Pakistan, the annual precipitation is projected to increase by 9.3-26.4\%, under SSP1-2.6, SSP2-4.5, and SSP5-8.5, respectively. For Sri Lanka, the annual precipitation is projected to increase by $6.6-21.2 \%$. With slight variations in the projected magnitudes, the present results are generally in agreement with previous studies (e.g. Caesar et al. 2015; NCHM 2019; Chaturvedi et al. 2012; MoFE 2019).

\subsection{Projected Changes in Seasonal Temperature and Precipitation}

\subsubsection{Projected Changes in Seasonal Temperature}

The projected changes in the seasonal mean temperature during winter and summer seasons show very similar spatial distributions over South Asia (Figs. 6, 7) as seen in the case of annual mean temperature (Fig. 2). The projected winter and summer temperatures increase over South Asia under all scenarios (Table 3). The projected warming over the northern part of South Asia is higher than over the southern part. The projected changes in the seasonal mean temperature averaged over South Asian countries for three future time slices under three SSPs are given in Table 4. By the end of the areas around each curve represent the likely range (66\% of the projected changes). The curves are obtained by taking the difference of each future year with respect to the average from the historical period (1995-2014), and then taking the 7-year running average afterward

twenty-first century, the winter temperature over South Asia is projected to increase by $1.3{ }^{\circ} \mathrm{C}, 2.4{ }^{\circ} \mathrm{C}$, and $4.8^{\circ} \mathrm{C}$, under SSP1-2.6, SSP2-4.5, and SSP5-8.5, respectively. Meanwhile, the summer temperature is projected to increase by $1.0^{\circ} \mathrm{C}$, $2.8^{\circ} \mathrm{C}$ ), and $3.8^{\circ} \mathrm{C}$ under SSP1-2.6, SSP2-4.5, and SSP5-8.5, respectively. Similar to the annual mean changes the seasonal temperature also shows more increase towards the end of the twenty-first century, at least for the SSP2 and SSP3 scenarios. The projected seasonal temperature over different countries in South Asia shows continuous warming, while the largest increase in the projected temperature is noticed over Pakistan during both seasons under all scenarios (Table 4). The above results indicate enhanced warming in winter as compared with the summer over South Asia.

\subsubsection{Projected Changes in Seasonal Precipitation}

The South Asia region is strongly influenced by the seasonal transition of winds. During summer, the southwesterly winds associated with the monsoon dominates the region. A large proportion of the population residing in South Asia depends on summer monsoon precipitation. The variation in this precipitation, and the associated floods and droughts, directly affects the lives and socioeconomic conditions of the 

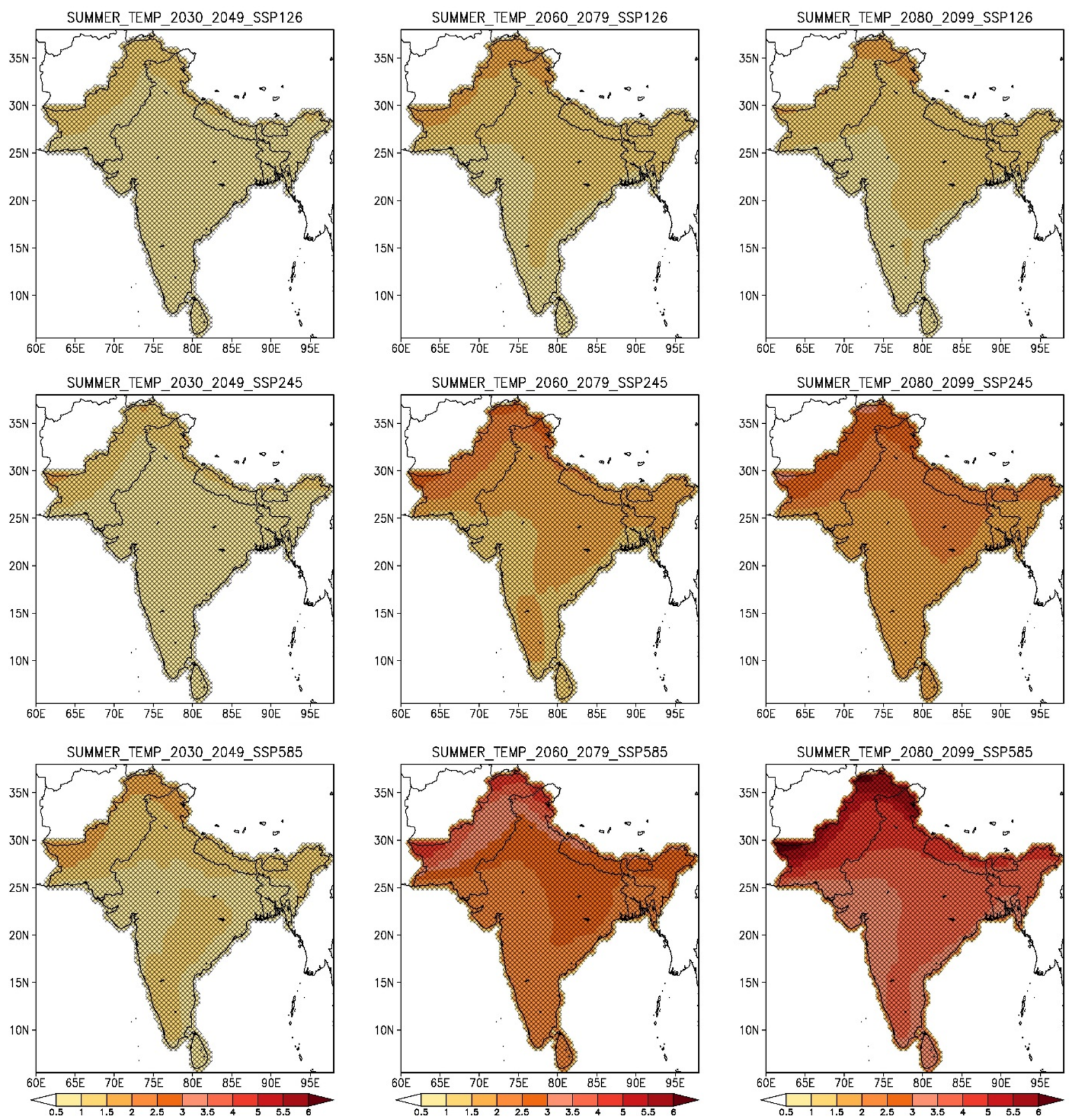

Fig. 6 Same as Fig. 2, except showing projected changes in mean temperature for the summer season

people there. It is therefore important to understand how the summer monsoon mean precipitation may vary over South Asia under different future scenarios. Figure 8 shows the spatial distribution of the projected changes in the summer season (June-September) precipitation over South Asia for the near-, mid-, and far-future periods. The projections show increased summer monsoon precipitation over large parts of South Asia under all three SSPs. The projected changes in the spatial pattern of monsoon precipitation (Fig. 8) resemble the projected changes for annual mean precipitation (Fig. 4). This is because by far the largest contribution to the annual precipitation over South Asia is from the summer monsoon. The northern part of Pakistan shows a reduction in summer monsoon rainfall, while the southern part shows enhanced monsoon rainfall. For the near-future period, eastern India and adjacent areas of Bangladesh show 

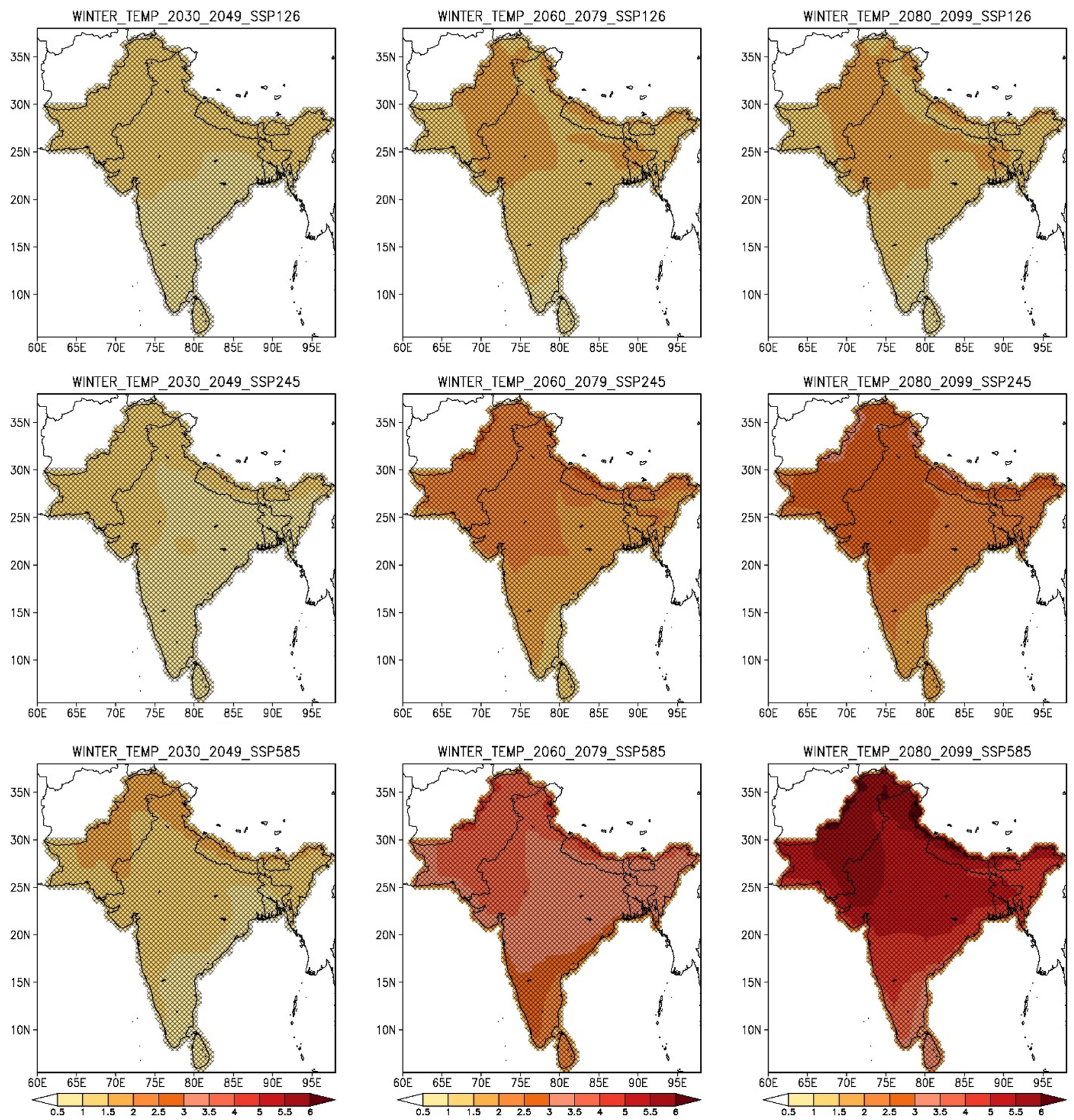

Fig. 7 Same as Fig. 2, except showing projected changes in mean temperature for the winter season

inconsistent changes in the mean summer monsoon precipitation under the SSP2-4.5 and SSP5-8.5 scenarios. Moreover, small areas in the foothills of the eastern Himalayas also show inconsistent changes in monsoon precipitation in the far-future period. Overall, the projected summer monsoon rainfall shows an increase in the future over most of South Asia. Table 4 summarizes the projected changes in summer and winter season precipitation over South Asia and its constituent countries. The domain-averaged summer monsoon precipitation over South Asia is projected to increase from 12.2 to $36.1 \%$ in the future, under three the SSPs, respectively (Table 4). The largest increase in the projected mean monsoon rainfall further is noticed towards the end of the twenty-first century.

By the end of the twenty-first century, the mean summer precipitation over South Asia is likely to increase by 
Table 3 Trends in temperature $\left({ }^{\circ} \mathrm{C}\right.$ decade $\left.^{-1}\right)$ and precipitation $\left(\%\right.$ decade $\left.^{-1}\right)$ in six South Asian countries and for entire South Asia under three SSP scenarios for the period 2030-2099

\begin{tabular}{lllllllll}
\hline & Scenario & BAN & BHU & IND & NEP & PAK & SRI & South Asia \\
\hline Temperature & SSP1-2.6 & 0.07 & 0.06 & 0.06 & 0.08 & 0.08 & 0.05 & 0.07 \\
& SSP2-4.5 & 0.23 & 0.26 & 0.25 & 0.28 & 0.29 & 0.19 & 0.26 \\
& SSP5-8.5 & 0.59 & 0.63 & 0.59 & 0.64 & 0.70 & 0.45 & 0.61 \\
Precipitation & SSP1-2.6 & 0.62 & 0.67 & 0.55 & 0.63 & $-0.23^{*}$ & 0.09 & 0.41 \\
& SSP2-4.5 & 0.88 & 1.12 & 1.06 & 0.76 & 0.28 & 1.01 & 0.91 \\
& SSP5-8.5 & 2.79 & 3.48 & 3.44 & 3.08 & 2.39 & 2.95 & 3.24 \\
\hline
\end{tabular}

All trends are significant at $99 \%$ confidence level. The only insignificant trend in precipitation over Pakistan under SSP1-2.6 is shown by the asterisk $\left(^{*}\right)$
$12.8 \%, 15.2 \%$, and $36.1 \%$ under the SSP1-2.6, SSP2-4.5, and SSP5-8.5 scenarios, respectively. Previous studies (Jena et al. 2016; Kitoh 2017; Ogata et al. 2014; Seth et al. 2013; Sharmila et al. 2015) using CMIP5 model datasets also detected an increase in the South Asia summer monsoon mean rainfall in any likely future climate. This increase in summer monsoon mean rainfall is primarily governed by enhanced thermodynamic conditions due to atmospheric warming (Sharmila et al. 2015). By the end of the twentyfirst century, the multimodel ensemble projected an increase in the summer monsoon mean precipitation by $16.5 \%$, 20.9\%, 27.9\%, 27.8\%, 53.7\% , and 32.0\% over Bangladesh, Bhutan, India, Nepal, Pakistan, and Sri Lanka, respectively, under the high-emission scenario SSP5-8.5. On the other hand, the projected winter precipitation over South Asia shows a reduction over most of Pakistan (below $35^{\circ} \mathrm{N}$ ), Nepal, Bhutan, Bangladesh, and adjacent southeastern parts of India in the near future under the three SSP scenarios (Fig. 9). The projected precipitation spatial pattern in the summer season strongly resembles the annual mean precipitation pattern, indicating that the largest contribution to the annual mean precipitation comes from the summer season monsoon (Figs. 4, 8).

For the near-future period, the projected winter precipitation also reveals significant and robust increases over northern Pakistan (above $35^{\circ} \mathrm{N}$ ) and adjacent areas of India under the three future scenarios. The projected winter precipitation also shows insignificant increases over central and southern India and Sri Lanka. Winter precipitation is projected to increase over a large part of South Asia in the midfuture period. In the far-future period (Fig. 9, right panel), the projected winter precipitation shows a reduction over southwestern Pakistan, Nepal, Bhutan, and adjacent areas, while significant and robust increases in winter precipitation are projected over northern Pakistan (above $35^{\circ} \mathrm{N}$ ) and the northwestern and southern parts of India. It is interesting to note that the multimodel ensemble projected robust and significant increases (reductions) in winter precipitation over the western (eastern) Himalayas under all three scenarios for both near- and far-future periods (Fig. 9).

\subsection{Assessment of Uncertainties in Temperature and Precipitation Signal}

The future climate projections are not free from uncertainties. Various sources contribute to these uncertainties, including (1) internal variability of the climate system, (2) inter-model variability, and (3) variability between different emission scenarios. We examined the likelihood of the projected temperature and precipitation associated with inter-model variability over South Asia. As mentioned earlier, the likely range is defined as spanning the 17 th to $83 \mathrm{rd}$ percentile around the median. Here we refer to this likely range as the "uncertainty range", while values outside this uncertainty range are considered less likely and therefore not discussed here. The projected changes in the annual mean temperature spatially averaged over South Asia as well as over six countries within South Asia are shown in Fig. 10. For the near (mid) future period, the uncertainty in projected annual mean temperature over South Asia ranges from 0.7 to $1.3(0.9-1.8)^{\circ} \mathrm{C}, 0.7$ to $1.2(1.5-2.3)^{\circ} \mathrm{C}$, and 0.8 to 1.5 (2.4-3.8) ${ }^{\circ} \mathrm{C}$ under SSP1-2.6, SSP2-4.5, and SSP58.5 , respectively. The projected uncertainty range increases as time progresses. By the end of the twenty-first century, the projected uncertainty in annual mean temperature over South Asia is $0.8-1.8^{\circ} \mathrm{C}, 1.6-2.9^{\circ} \mathrm{C}$, and $3.4-5.5^{\circ} \mathrm{C}$ under SSP1-2.6, SSP2-4.5, and SSP5-8.5, respectively.

The uncertainty in the projected temperature for each country in South Asia also varies widely. Table 5 summarizes the uncertainty associated with temperature and precipitation projections for near-, mid-, and far-future periods. The uncertainty associated with temperature and precipitation increases towards the end of the twenty-first century. By the end of the twenty-first century, the uncertainty associated with annual mean temperature over Bangladesh ranges from 0.8 to $1.6{ }^{\circ} \mathrm{C}, 1.6$ to $2.7{ }^{\circ} \mathrm{C}$, and 3.1 to $5.1{ }^{\circ} \mathrm{C}$ for SSP12.6, SSP2-4.5, and SSP5-8.5, respectively. The uncertainty in projected annual mean temperature over Bhutan is projected to be from 0.8 to $1.8^{\circ} \mathrm{C}, 1.8$ to $3.1^{\circ} \mathrm{C}$, and 3.6 to $6.0^{\circ} \mathrm{C}$ for SSP1-2.6, SSP2-4.5, and SSP5-8.5, respectively. For India, the uncertainty range is from 0.8 to $1.8^{\circ} \mathrm{C}, 1.6$ to $2.8^{\circ} \mathrm{C}$, and 3.2 to $5.4{ }^{\circ} \mathrm{C}$ for SSP1-2.6, SSP2-4.5, and 


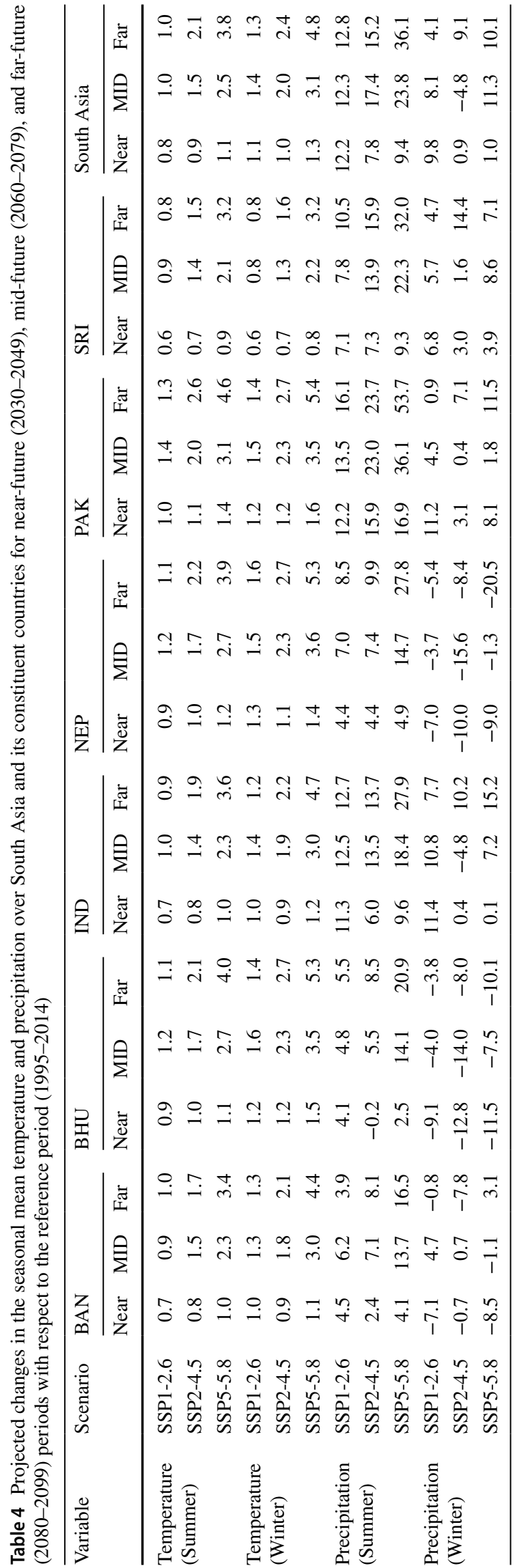

SSP5-8.5, respectively. For Nepal, uncertainty in projected annual temperature varies from 0.9 to $1.9^{\circ} \mathrm{C}, 1.9$ to $3.2^{\circ} \mathrm{C}$, and 3.7 to $6.2^{\circ} \mathrm{C}$ under SSP1-2.6, SSP2-4.5, and SSP5-8.5, respectively. For Pakistan, the uncertainty is projected to be from 0.9 to $2.1{ }^{\circ} \mathrm{C}, 2.0$ to $3.2{ }^{\circ} \mathrm{C}$, and 4.0 to $6.3{ }^{\circ} \mathrm{C}$ for SSP1-2.6, SSP2-4.5, and SSP5-8.5, respectively, while for Sri Lanka the uncertainty range is $0.5-1.3{ }^{\circ} \mathrm{C}, 1.2-2.2{ }^{\circ} \mathrm{C}$, and $2.4-4.2{ }^{\circ} \mathrm{C}$ for SSP1-2.6, SSP2-4.5, and SSP5-8.5, respectively.

The future projections indicate more warming in the winter season than in the summer over South Asia under all future scenarios (Table 4). The uncertainty associated with the winter temperature increases with time. This is especially evident for the high-emission SSP5-8.5 scenario. The uncertainty associated with projected temperature over different South Asian countries is listed in Table 5. By the end of the twenty-first century, the uncertainty associated with winter temperature over South Asia is projected to be $1.0-2.0^{\circ} \mathrm{C}$, 1.8-3.2 ${ }^{\circ} \mathrm{C}$, and $3.8-6.0{ }^{\circ} \mathrm{C}$ under SSP1-2.6, SSP2-4.5, and SSP5-8.5, respectively. Meanwhile, the uncertainty associated with summer temperature is projected to be $0.6-1.7^{\circ} \mathrm{C}$, 1.3-3.0 ${ }^{\circ} \mathrm{C}$, and $2.8-5.2{ }^{\circ} \mathrm{C}$ under SSP1-2.6, SSP2-4.5, and SSP5-8.5, respectively.

As discussed earlier, precipitation displays large spatial variability as compared with temperature on both annual and seasonal time scales. The uncertainty in the projected precipitation varies widely over South Asia. By the end of the twenty-first century, the uncertainty associated with annual mean precipitation over South Asia is projected to be $0.0-20.5 \%, 0.4-24.8 \%$, and $14.5-43.7 \%$ under SSP1-2.6, SSP2-4.5, and SSP5-8.5, respectively (Table 5).

By the end of the twenty-first century, the uncertainty associated with annual mean precipitation over Bangladesh is -0.7 to $11.6 \%,-1.7$ to $14.7 \%$, and 9.3 to $36.3 \%$ under SSP1-2.6, SSP2-4.5, and SSP5-8.5, respectively (Fig. 11). Over Bhutan, the uncertainty in annual precipitation is projected to be -1.8 to $10.2 \%,-2.3$ to $12.7 \%$, and 5.3 to $33.4 \%$ under SSP1-2.6, SSP2-4.5, and SSP5-8.5, respectively. For India, the uncertainty range is projected to be 0.6 to $18.9 \%$, 1.7 to $27.0 \%$, and 14.6 to $44.6 \%$ under SSP1-2.6, SSP2-4.5, and SSP5-8.5, respectively. The uncertainty in annual precipitation over Nepal is projected to be -0.2 to $9.5 \%,-1.2$ to $14.5 \%$, and 8.8 to $30.8 \%$ under SSP1-2.6, SSP2-4.5, and SSP5-8.5, respectively. The projected uncertainty in annual precipitation over Pakistan is -7.3 to $28.2 \%,-3.8$ to $39.4 \%$, and 12.9 to $80.0 \%$ under SSP1-2.6, SSP2-4.5, and SSP58.5 , respectively. For Sri Lanka, the uncertainty in projected annual precipitation ranges from 0.9 to $15.9 \%, 2.5$ to $18.3 \%$, and 9.7 to $29.1 \%$ under SSP1-2.6, SSP2-4.5, and SSP5-8.5, respectively. The full range (i.e., results from all models) shows enhanced spread in uncertainty as compared with the $66 \%$ likely range, but for the sake of brevity is not discussed here (please see Table S2 for more detail). 

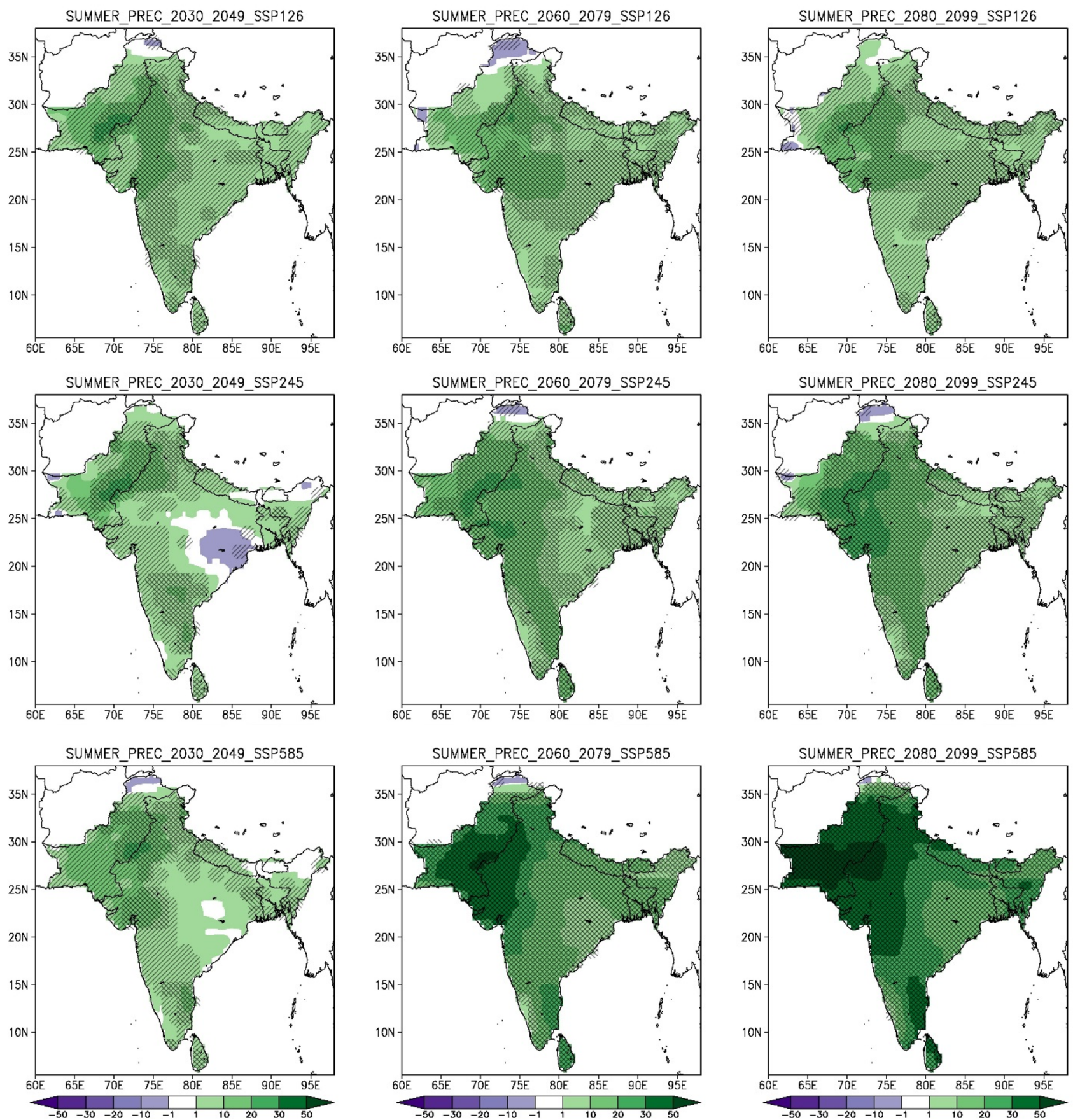

Fig. 8 Same as Fig. 4, except showing the summer mean precipitation change, expressed as a percentage

We also examined the uncertainty in the simulated summer monsoon over South Asia. The uncertainty in the summer monsoon increases towards the end of the twenty-first century. By the end of the twenty-first century, the uncertainty associated with summer monsoon precipitation over South Asia is projected to be -2.9 to $24.7 \%, 2.1$ to $36.3 \%$, and 11.3 to $63.0 \%$ under SSP1-2.6, SSP2-4.5, and SSP5-8.5 scenarios, respectively. Under the high-emission SSP5-8.5 scenario, the uncertainty associated with summer monsoon precipitation over Bangladesh, Bhutan, India, Nepal, Pakistan, and Sir Lanka is projected to 7.5 to $36.9 \%, 2.1$ to $43.0 \%, 14.0$ to $62.7 \%, 13.5$ to $46.5 \%, 14.6$ to $156.8 \%$, and 15.9 to $63.4 \%$, respectively, by the end of the twenty-first century. 

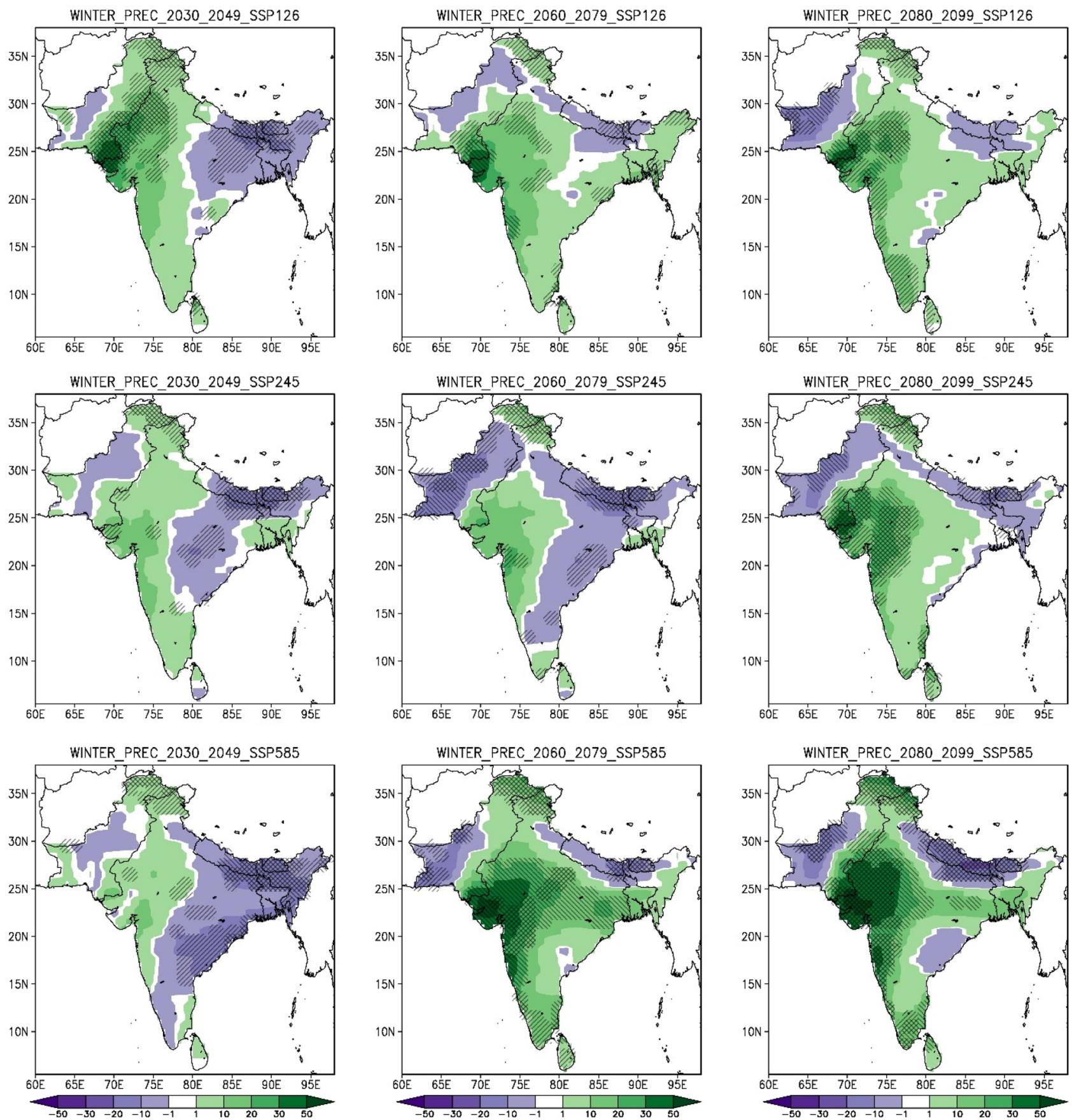

Fig. 9 Same as Fig. 6, except showing the winter mean precipitation change, expressed as a percentage

\subsection{Trends in Projected Temperature and Precipitation}

Trends in projected temperature and precipitation from 2030 to 2099 are shown in Table 3. For all scenarios, temperature shows a $99 \%$ significant increasing trend for each country as well as over South Asia as a whole. For SSP12.6, SSP2-4.5, and SSP5-8.5, the trends in temperature over South Asia are $0.07,0.26$, and $0.61{ }^{\circ} \mathrm{C} \mathrm{decade}{ }^{-1}$, respectively. Being closer to the equator, Sri Lanka shows the lowest trends among the countries. For precipitation, almost all the trends remain significant at $99 \%$ except for Pakistan under the SSP1-2.6 scenario. For SSP1-2.6, SSP2-4.5, and SSP5-8.5, the precipitation over South Asia shows decadal trends of $0.41,0.91$, and $3.24 \%$ decade $^{-1}$, respectively. Note that for South Asia, as well as for its representative countries, the precipitation trends are proportional to the increase in warming. 


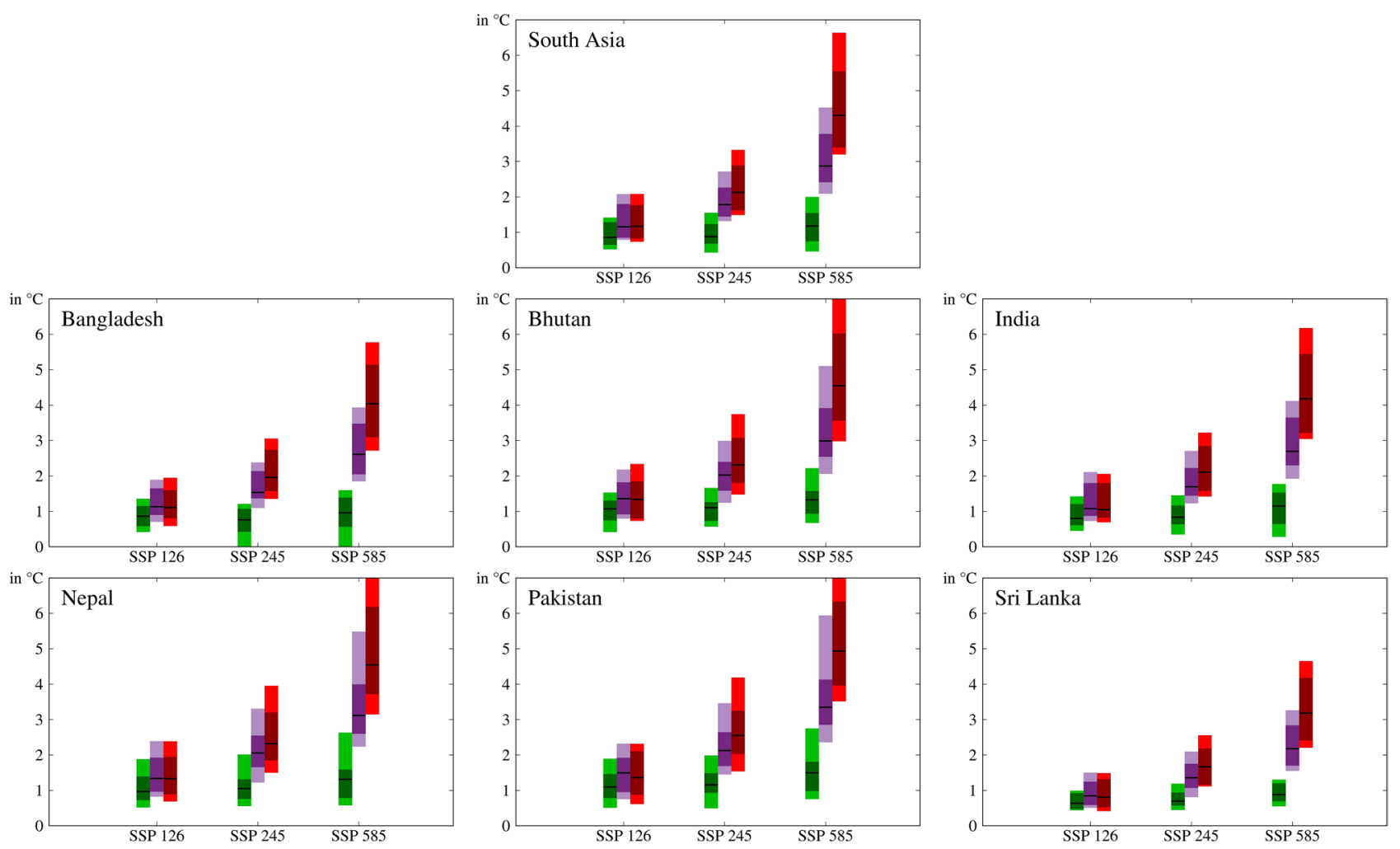

Fig. 10 Projected changes in annual temperature spatially averaged over the six countries as well as over the entire South Asia. The green, magenta, and red bars represent the projected values for the near future (2030-2049), mid-century (2060-2079), and far future (2080-2099), respectively, with reference to the base period (1995-
2014), for the three scenarios (SSP1-2.6, SSP2-4.5, and SSP5-8.5). The black line in each bar shows the projected changes for the median values. The length of the bars shows the full ranges (results from all the models), and the dark green, dark magenta, and dark red colors in each bar show the $66 \%$ likely ranges
Table 5 The uncertainty (66\% likely range) associated with the projected changes in temperature $\left({ }^{\circ} \mathrm{C}\right)$ and precipitation (\%) over South Asia and its constituent countries for near (2030-2049), mid (2060-
2079), and far (2080-2099) periods as compared with the reference period (1995-2014) under three SSP scenarios

\begin{tabular}{|c|c|c|c|c|c|c|c|c|c|c|c|c|c|c|c|c|c|c|c|}
\hline \multirow[t]{3}{*}{ Variable } & \multirow[t]{3}{*}{ Country } & \multicolumn{6}{|c|}{ SSP1-2.6 } & \multicolumn{6}{|c|}{ SSP2-4.5 } & \multicolumn{6}{|c|}{ SSP5-8.5 } \\
\hline & & \multicolumn{2}{|l|}{ Near } & \multicolumn{2}{|l|}{ Mid } & \multicolumn{2}{|l|}{ Far } & \multicolumn{2}{|l|}{ Near } & \multicolumn{2}{|l|}{ Mid } & \multicolumn{2}{|l|}{ Far } & \multicolumn{2}{|l|}{ Near } & \multicolumn{2}{|l|}{ Mid } & \multicolumn{2}{|l|}{ Far } \\
\hline & & Min & Max & Min & Max & Min & Max & Min & Max & Min & Max & Min & Max & Min & Max & Min & Max & Min & Max \\
\hline \multirow[t]{7}{*}{ Temperature } & South Asia & 0.7 & 1.3 & 0.9 & 1.8 & 0.8 & 1.8 & 0.7 & 1.2 & 1.5 & 2.3 & 1.6 & 2.9 & 0.8 & 1.5 & 2.4 & 3.8 & 3.4 & 5.5 \\
\hline & Bangladesh & 0.6 & 1.1 & 0.9 & 1.6 & 0.8 & 1.6 & 0.4 & 1.1 & 1.4 & 2.1 & 1.6 & 2.7 & 0.6 & 1.4 & 2.1 & 3.5 & 3.1 & 5.1 \\
\hline & Bhutan & 0.8 & 1.3 & 0.9 & 1.8 & 0.8 & 1.8 & 0.7 & 1.2 & 1.6 & 2.4 & 1.8 & 3.1 & 0.9 & 1.6 & 2.6 & 3.9 & 3.6 & 6.0 \\
\hline & India & 0.6 & 1.2 & 0.9 & 1.8 & 0.8 & 1.8 & 0.6 & 1.2 & 1.5 & 2.2 & 1.6 & 2.8 & 0.7 & 1.5 & 2.3 & 3.6 & 3.2 & 5.4 \\
\hline & Nepal & 0.7 & 1.4 & 1.0 & 1.9 & 0.9 & 1.9 & 0.8 & 1.3 & 1.7 & 2.5 & 1.9 & 3.2 & 0.8 & 1.6 & 2.6 & 4.0 & 3.7 & 6.2 \\
\hline & Pakistan & 0.8 & 1.5 & 1.0 & 1.9 & 0.9 & 2.1 & 0.9 & 1.5 & 1.7 & 2.6 & 2.0 & 3.2 & 1.0 & 1.8 & 2.9 & 4.1 & 4.0 & 6.3 \\
\hline & Sri Lanka & 0.5 & 0.9 & 0.6 & 1.2 & 0.5 & 1.3 & 0.6 & 0.9 & 1.1 & 1.7 & 1.2 & 2.2 & 0.7 & 1.2 & 1.7 & 2.8 & 2.4 & 4.2 \\
\hline \multirow[t]{7}{*}{ Precipitation } & South Asia & 1.9 & 17.3 & 1.4 & 17.3 & 0.0 & 20.5 & 0.3 & 14.2 & 3.0 & 20.0 & 0.4 & 24.8 & 0.5 & 11.9 & 6.5 & 31.3 & 14.5 & 43.7 \\
\hline & Bangladesh & -2.9 & 8.2 & 1.8 & 9.5 & -0.7 & 11.6 & -4.3 & 8.9 & 0.1 & 13.7 & -1.7 & 14.7 & -3.8 & 9.5 & 2.8 & 21.2 & 9.3 & 36.3 \\
\hline & Bhutan & -3.2 & 4.6 & -1.1 & 10.2 & -1.8 & 10.2 & -3.7 & 6.2 & -4.1 & 12.0 & -2.3 & 12.7 & -5.7 & 7.0 & -1.7 & 19.6 & 5.3 & 33.4 \\
\hline & India & 2.9 & 21.0 & 0.5 & 18.1 & 0.6 & 18.9 & 1.3 & 11.9 & 1.6 & 20.3 & 1.7 & 27.0 & -0.4 & 14.5 & 6.4 & 34.6 & 14.6 & 44.6 \\
\hline & Nepal & -1.8 & 9.2 & -1.1 & 12.6 & -0.2 & 9.5 & -2.1 & 6.3 & -3.0 & 11.7 & -1.2 & 14.5 & -2.7 & 7.6 & 6.5 & 18.9 & 8.8 & 30.8 \\
\hline & Pakistan & -0.3 & 24.0 & -5.1 & 23.5 & -7.3 & 28.2 & -3.0 & 22.2 & -2.2 & 32.2 & -3.8 & 39.4 & -1.3 & 23.2 & 1.5 & 47.2 & 12.9 & 80.0 \\
\hline & Sri Lanka & -1.6 & 12.8 & -0.2 & 19.1 & 0.9 & 15.9 & -1.6 & 9.3 & 0.3 & 24.5 & 2.5 & 18.3 & -2.3 & 10.5 & 3.9 & 21.7 & 9.7 & 29.1 \\
\hline
\end{tabular}



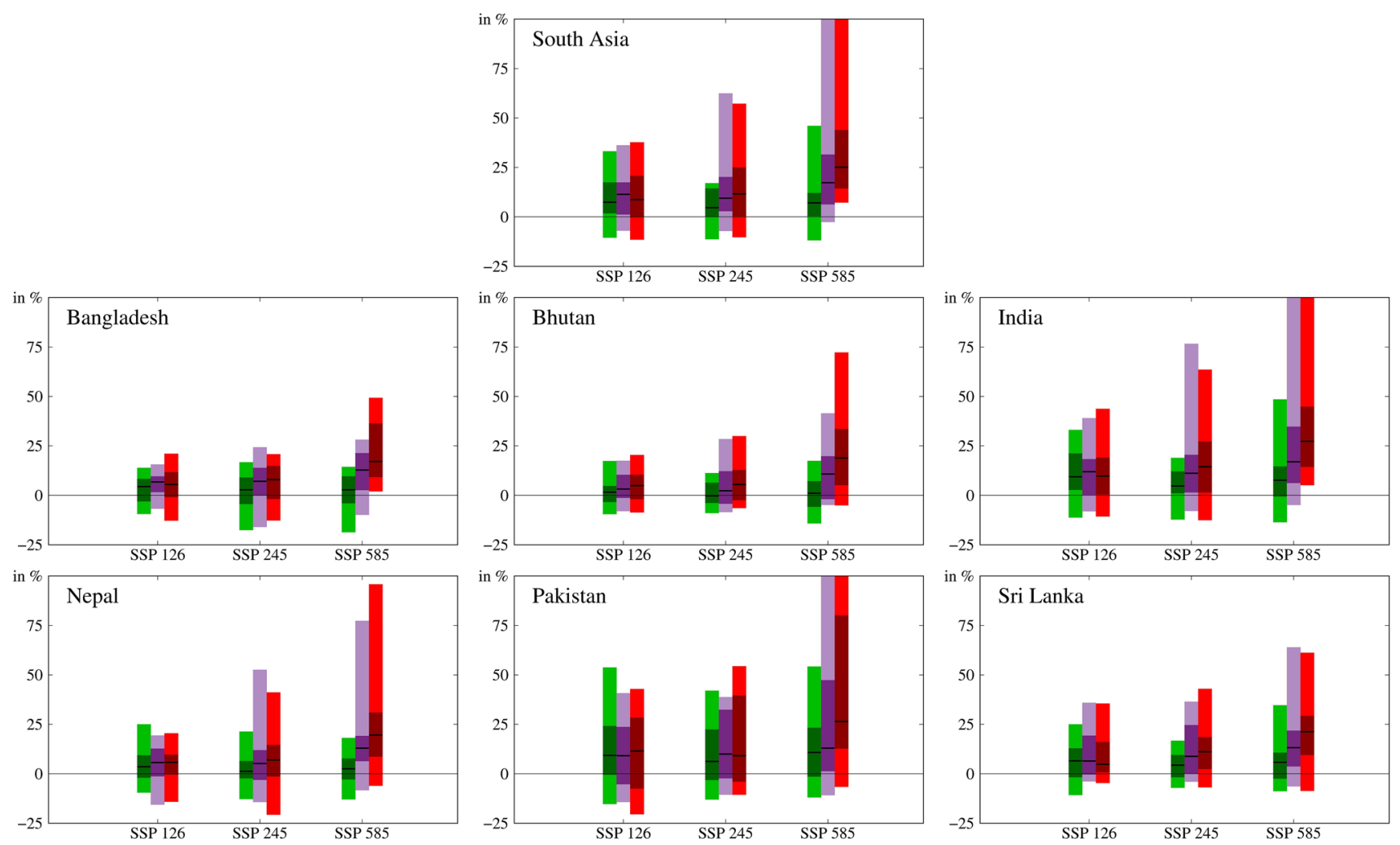

Fig. 11 Same as Fig. 10, except showing changes for precipitation. The green, magenta, and red bars represent the projected values for the near future (2030-2049), mid-century (2060-2079), and far future (2080-2099), respectively, with reference to the base period (19952014) for the three scenarios (SSP1-2.6, SSP2-4.5, and SSP5-8.5).

\subsection{Difference Between CMIP6- and CMIP5-Projected Signals over South Asia}

We further examined the difference between the CMIP6 and CMIP5 simulated climate response to anthropogenic forcing over South Asia. For this purpose, we computed the difference between projected annual mean temperature and precipitation over South Asia for medium-emission SSP24.5 (RCP4.5) and high-emission SSP5-8.5 (RCP8.5) scenarios. Figure 12 shows the difference between the CMIP6 and CMIP5 projected temperature signals over South Asia. The CMIP6 models show higher warming $\left(1-3{ }^{\circ} \mathrm{C}\right)$ over the irrigated plains of Indus and Ganges in the near-, mid-, and far-future periods under both scenarios (Fig. 12). Compared with the CMIP5 models, the warming projected by the CMIP6 models increases towards the end of the twenty-first century. By the end of the twenty-first century, large parts of South Asia display more warming in the CMIP6 simulations than in the CMIP5 one. Figure 13 shows that the warming over the irrigated plains of Indus and Ganges is associated with a stark reduction in precipitation due to the strong land-atmosphere coupling over the region, as mentioned in
The black line in each bar shows the projected changes for the median values. The length of the bars shows full ranges (results from all the models), and the dark green, dark magenta, and dark red colors in each bar show the $66 \%$ likely ranges

earlier studies (Saeed et al. 2009). The CMIP6 simulations show more future precipitation over the Western Ghats, central and northwestern parts India, and adjacent areas of southern Pakistan, northern Pakistan, Nepal, Bhutan, and Bangladesh than the CMIP5 models do. The increase in precipitation in CMIP6 simulations relative to CMIP5 is most pronounced towards the end of the twenty-first century. In general, the CMIP6 models display higher climate sensitivity to anthropogenic greenhouse gas emissions as compared with the CMIP5 models over the South Asia region.

\section{Summary and Conclusions}

The Coupled Model Intercomparison Project phase 6 (informally known as CMIP6) simulations employed new Shared Socioeconomic Pathways to access the future global climate change. The CMIP6 simulations differ from those performed in the earlier phases of CMIP (i.e., CMIP3 and CMIP5) due to a different start year for the future scenarios, as well as a new set of specifications for concentration, emission, and land-use scenarios (Gidden et al. 2019). Our results indicate 

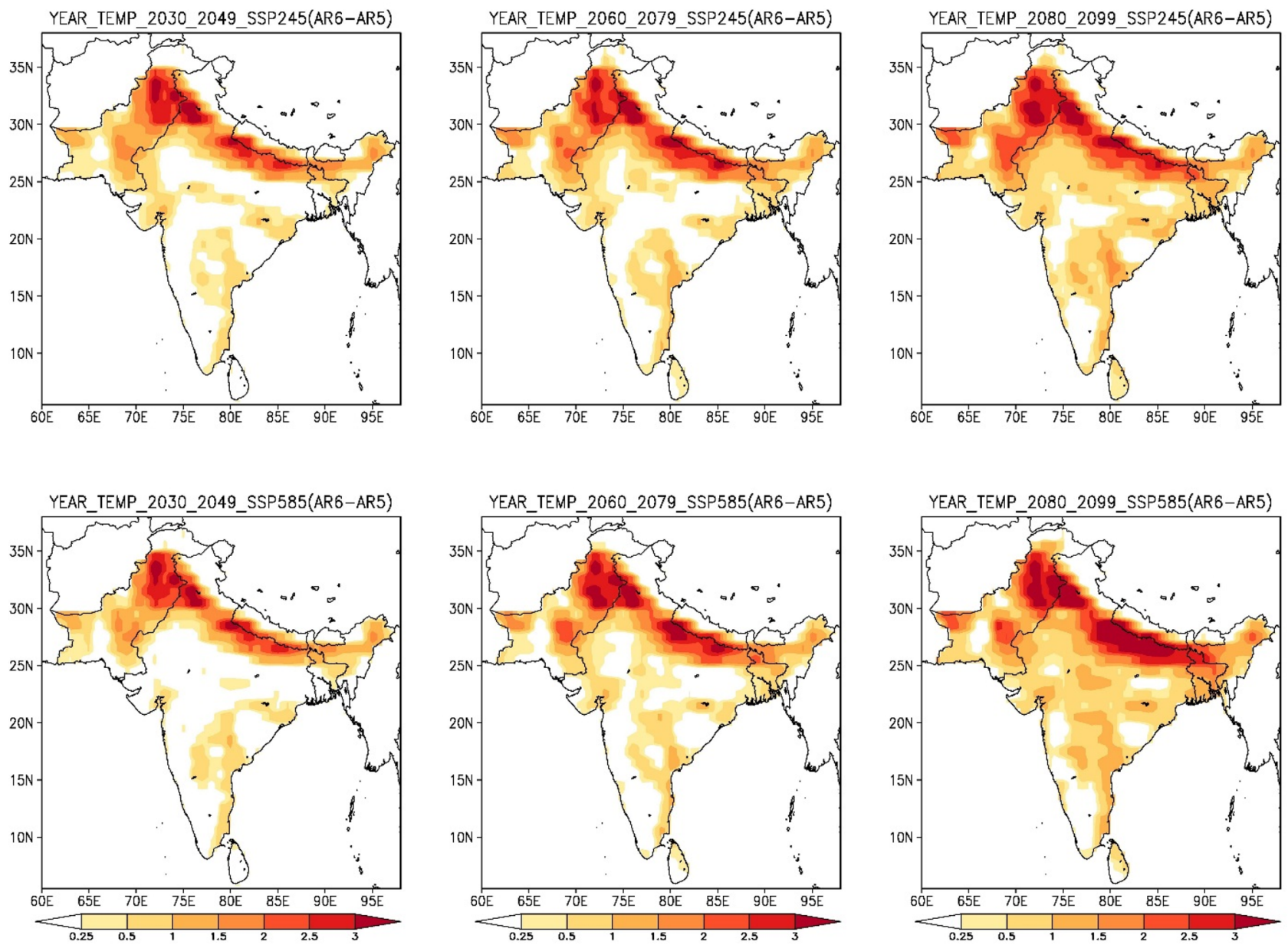

Fig. 12 Difference in the projected annual mean temperature over South Asia between CMIP6 and CMIP5 datasets. The difference (CMIP6 minus CMIP5) in projected signals is obtained for median

that the regional-scale climate response to anthropogenic forcing employed in the CMIP6 models differs from that of CMIP5 models. A comparison between the CMIP6 (Table 1) and CMIP5 (Table S1) model simulations indicates higher sensitivity to greenhouse gas emissions in the CMIP6 models as compared with CMIP5 over the South Asia region. The CMIP6 models predict more warming $\left(1-3{ }^{\circ} \mathrm{C}\right)$ over the irrigated plains of the Indus and Ganges in the near (2030-2049), mid (2060-2079), and far (2080-2099) future periods relative to the CMIP5 dataset. The enhanced future warming over the irrigated plains of South Asia may be attributed to the reduction in precipitation over the same region. Irrigation plays an important role in controlling the patterns of temperature and precipitation over this region (Saeed et al. 2009).

The multimodel ensemble from 27 CMIP6 models reveals a continuous increase in the annual mean temperature over South Asia during the twenty-first century under three SSP scenarios (i.e., SSP1-2.6, SSP2-4.5, and SSP58.5). The northwestern parts of South Asia, including values for three future periods, i.e., the near (2030-2049), mid (2060 2079), and far (2080-2099) future periods

Pakistan and adjacent parts of India, Nepal, and the western Himalayas, are projected to experience the largest increase in future temperature (exceeding $6{ }^{\circ} \mathrm{C} ;$ Fig. 2) by the end of the twenty-first century under SSP5-8.5 relative to the reference climate (1995-2014). The projected warming signals over South Asia are robust, and more than $66 \%$ of the models agree with the sign of the temperature change in future climates. Under all three future scenarios, the projected temperature increases more towards the end of the twenty-first century (Table 2). By the end of the twenty-first century, the annual mean temperature averaged over South Asia is projected to increase by $1.2{ }^{\circ} \mathrm{C}$, $2.1{ }^{\circ} \mathrm{C}$, and $4.3{ }^{\circ} \mathrm{C}$ under SSP1-2.6, SSP2-4.5, and SSP58.5 scenarios, respectively. The country-averaged annual mean temperatures also show a robust increases relative to the reference climate under all emission scenarios (Table 2). By the end of the twenty-first century, the annual mean temperature over Bangladesh, Bhutan, India, Nepal, Pakistan, and Sri Lanka is projected to increase by 

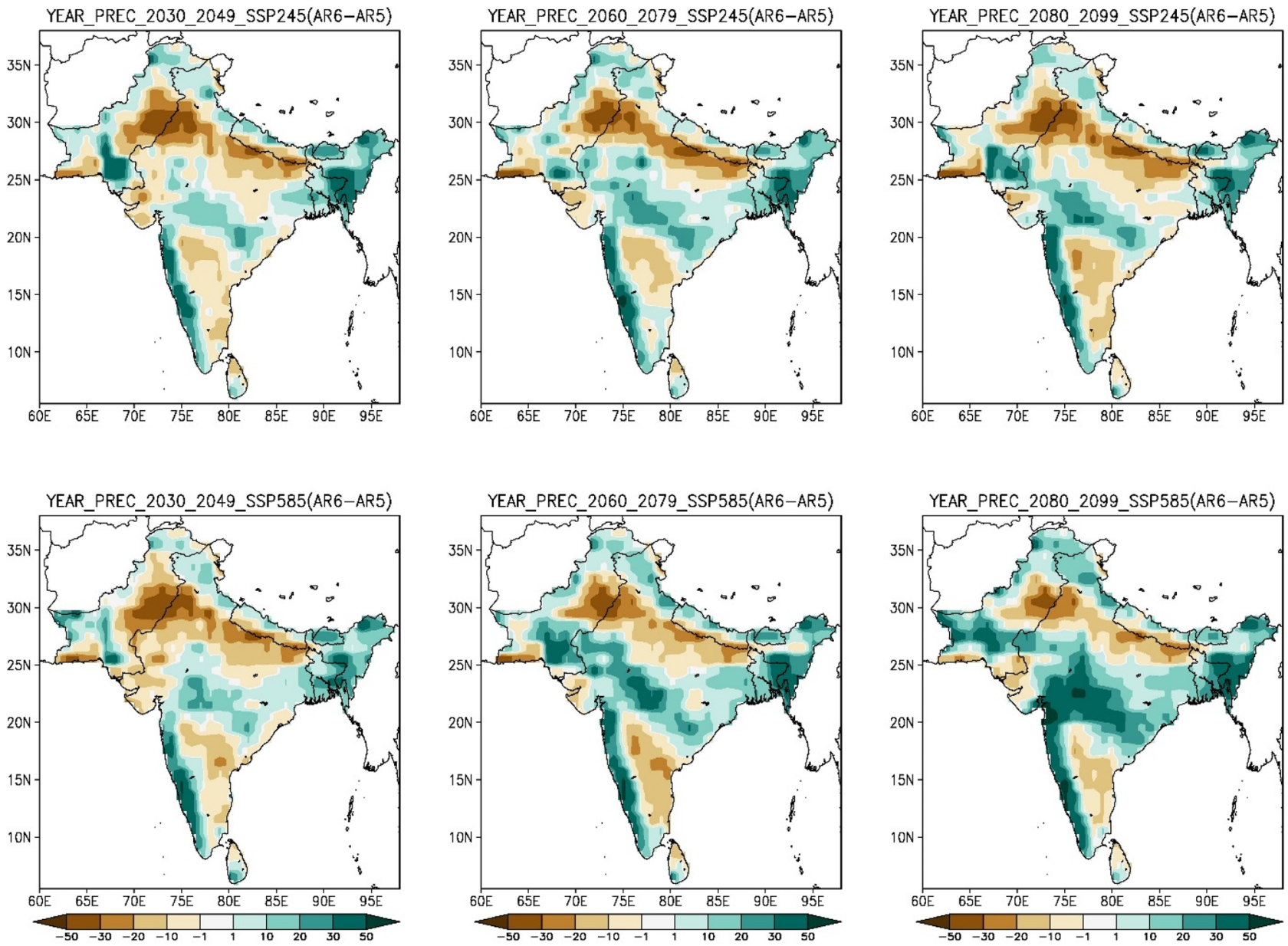

Fig. 13 Same as Fig. 12, except showing the difference for annual mean precipitation

$4.0{ }^{\circ} \mathrm{C}, 4.5^{\circ} \mathrm{C}, 4.2{ }^{\circ} \mathrm{C}, 4.5{ }^{\circ} \mathrm{C}, 4.9^{\circ} \mathrm{C}$, and $3.2{ }^{\circ} \mathrm{C}$, respectively, under SSP5-8.5 (see Table 2 for more detail). In all cases, the northern parts of South Asia, including Pakistan and adjacent areas of northwestern India and Nepal, are projected to warm more than the southern parts during the twenty-first century. The uncertainty associated with temperature projections over South Asia and its constituent countries is small in the near- and mid-future periods as compared with the far-future period (see Table 5, Table S2). By the end of the twenty-first century, the uncertainty in the projected temperature (Table 5) over South Asia ranges from 0.8 to $1.8^{\circ} \mathrm{C}, 1.6$ to $2.9^{\circ} \mathrm{C}$, and 3.4 to $5.5^{\circ} \mathrm{C}$ under SSP1-2.6, SSP2-4.5, and SSP5-8.5, respectively. The projected uncertainty varies for different countries. By the end of the twenty-first century, under SSP5-8.5, the uncertainty associated with annual mean temperature projections over Bangladesh, Bhutan, India, Nepal, Pakistan, and Sri Lanka ranges from 3.1 to $5.1{ }^{\circ} \mathrm{C}$, 3.6 to $6.0{ }^{\circ} \mathrm{C}, 3.2$ to $5.4{ }^{\circ} \mathrm{C}, 3.7$ to $6.2{ }^{\circ} \mathrm{C}, 4.0$ to $6.3{ }^{\circ} \mathrm{C}$, and 2.4 to $4.2^{\circ} \mathrm{C}$, respectively.
Precipitation, on the other hand, shows large spatial variability in the projected climates. Hence the uncertainty associated with precipitation is also larger than the uncertainty associated with temperature. There is little agreement among the CMIP6 models on projected precipitation signals for the near-future period, while agreement is better for the mid- and far-future periods. For the near-future period, the annual mean precipitation over South Asia is projected to increase by 10-20\% under SSP1-2.6 and SSP2-4.5, and by 10-30\% under SSP5-8.5. By the end of the twenty-first century, the annual mean precipitation is projected to increase by $10-20 \%$ under the SSP1-2.6 scenario, $10-30 \%$ under the SSP2-4.5 scenario, and 10-50\% under SSP5-8.5. The projected annual mean precipitation shows an increasing trend, significant at 99\%, over almost all South Asian countries during the twenty-first century. By the end of the twenty-first century, the annual mean precipitation averaged over the South Asia region is projected to increase by $8.7 \%$, $11.6 \%$, and 25.1\% under SSP1-2.6, SSP2-4.5, and SSP58.5 , respectively. The country-averaged annual mean precipitation is projected to increase by $17.1 \%$ over Bangladesh, 
$18.9 \%$ over Bhutan, $27.3 \%$ over India, $19.5 \%$ over Nepal, $26.4 \%$ over Pakistan, and $2.2 \%$ over Sri Lanka under the SSP5-8.5 scenario. During the winter season, there are large areas where the CMIP6 models are inconsistent in their projected precipitation change under different scenarios. However, there is a robust increase (reduction) in winter precipitation over the western (eastern) Himalayas in all cases. On the other hand, the summer monsoon precipitation shows a robust increase over most of the South Asia region, with the largest increase over southern Pakistan and adjacent areas of India. Under the SSP5-8.5 scenario, the summer monsoon precipitation averaged over South Asia is projected to increase by $12-36 \%$ by the end of the twentyfirst century.

The results of this study indicate that the northwestern part of the South Asia region is highly vulnerable to climate change due to the large increase in the projected annual, winter, and summer mean temperature. The enhanced future warming is likely to further accelerate the melting of glaciers and snowmelt over this region, which would severely impact the irrigation patterns downstream (Chaturvedi et al. 2014). Furthermore, the increase in summer precipitation, together with increased water in rivers due to glacier melt in summer, may cause extreme summer flash floods over this region in the future. The results presented in this study should be useful for impact studies and climate adaptation strategies for the South Asia region.

Acknowledgements The authors thank the three anonymous reviewers for their valuable comments and review. The present research has been supported financially by the Center of Excellence for Climate Change Research, King Abdulaziz University, Jeddah, Saudi Arabia. The authors acknowledge the World Climate Research Programme for making the CMIP6 dataset available for global- and regional-scale climate research. The authors also thank the Earth System Grid Federation (ESGF) for archiving and providing access to the CMIP6 dataset. The data analysis and all computational work carried out in this study were performed on the Aziz Supercomputer at King Abdulaziz University's High Performance Computing Center, Jeddah, Saudi Arabia.

\section{Compliance with Ethical Standards}

Conflict of interest The authors declare that they have no conflict of interest with regard to this article.

Open Access This article is licensed under a Creative Commons Attribution 4.0 International License, which permits use, sharing, adaptation, distribution and reproduction in any medium or format, as long as you give appropriate credit to the original author(s) and the source, provide a link to the Creative Commons licence, and indicate if changes were made. The images or other third party material in this article are included in the article's Creative Commons licence, unless indicated otherwise in a credit line to the material. If material is not included in the article's Creative Commons licence and your intended use is not permitted by statutory regulation or exceeds the permitted use, you will need to obtain permission directly from the copyright holder. To view a copy of this licence, visit http://creativecommons.org/licenses/by/4.0/.

\section{References}

Almazroui M, Nazrul Islam M, Saeed S, Alkhalaf AK, Dambul R (2017a) Assessment of uncertainties in projected temperature and precipitation over the Arabian Peninsula using three categories of Cmip5 multimodel ensembles. Earth Syst Environ 1(2):1-20. https://doi.org/10.1007/s41748-017-0027-5

Almazroui M, Saeed S, Islam MN, Khalid MS, Alkhalaf AK, Dambul R (2017b) Assessment of uncertainties in projected temperature and precipitation over the Arabian Peninsula: a comparison between different categories of CMIP3 models. Earth Syst Environ. https://doi.org/10.1007/s41748-017-0012-z

Annamalai H, Hamilton K, Sperber KR (2007) The South Asian summer monsoon and its relationship with ENSO in the IPCC AR4 simulations. J Clim. https://doi.org/10.1175/JCLI4035.1

Ashok K, Guan Z, Yamagata T (2001) Impact of the Indian Ocean dipole on the relationship between the Indian monsoon rainfall and ENSO. Geophys Res Lett. https://doi.org/10.1029/2001G L013294

Bandara JS, Cai Y (2014) The impact of climate change on food crop productivity, food prices and food security in South Asia. Econ Anal Policy. https://doi.org/10.1016/j.eap.2014.09.005

Bhatla R, Singh M, Pattanaik DR (2017) Impact of Madden-Julian oscillation on onset of summer monsoon over India. Theor Appl Climatol. https://doi.org/10.1007/s00704-015-1715-4

Bi D, Dix M, Marsland S, O'Farrell S, Rashid H, Uotila P, Hirst, Kowalczyk E, Golebiewski, Sullivan A, Yan Y, Franklin C, Hannah, Sun Z, Vohralik, Watterson, Fiedler R, Collier M, Puri K (2012) The ACCESS coupled model: description, control climate and evaluation. Aust Meteorol Oceanogr J 63:41-64. https://doi. org/10.22499/2.6301.004

Boos WR, Kuang Z (2010) Dominant control of the South Asian monsoon by orographic insulation versus plateau heating. Nature. https ://doi.org/10.1038/nature08707

Caesar J, Janes T, Lindsay A, Bhaskaran B (2015) Temperature and precipitation projections over Bangladesh and the upstream Ganges, Brahmaputra and Meghna systems. Environ Sci Process Impacts. https://doi.org/10.1039/c4em00650j

Cao J, Wang B, Yang Y-M, Ma L, Li J, Sun B, Bao Y, He J, Zhou X, Wu L (2018) The NUIST Earth System Model (NESM) version 3: description and preliminary evaluation. Geosci Model Dev 11:2975-2993. https://doi.org/10.5194/gmd-11-2975-2018

Chaturvedi RK, Joshi J, Jayaraman M, Bala G, Ravindranath NH (2012) Multi-model climate change projections for India under representative concentration pathways. Curr Sci 103:791-802

Chaturvedi Rajiv K, Kulkarni A, Karyakarte Y, Joshi J, Bala G (2014) Glacial mass balance changes in the Karakoram and Himalaya based on CMIP5 multi-model climate projections. Clim Change. https://doi.org/10.1007/s10584-013-1052-5

Dimri AP, Niyogi D, Barros AP, Ridley J, Mohanty UC, Yasunari T, Sikka DR (2015) Western disturbances: a review. Rev Geophys. https://doi.org/10.1002/2014RG000460

Eyring V, Bony S, Meehl GA, Senior C, Stevens B, Stouffer RJ, Taylor KE (2015) Overview of the Coupled Model Intercomparison Project Phase 6 (CMIP6) experimental design and organisation. Geoscientific Model Development Discussions. https://doi. org/10.5194/gmdd-8-10539-2015

Gidden MJ, Riahi K, Smith SJ, Fujimori S, Luderer G, Kriegler E, Takahashi K (2019) Global emissions pathways under different socioeconomic scenarios for use in CMIP6: a dataset of harmonized emissions trajectories through the end of the century. Geoscientific Model Development. https://doi.org/10.5194/gmd-12-1443-2019

Goswami BN (2012) South Asian monsoon. In: Intraseasonal variability in the atmosphere-ocean climate system. https://doi. org/10.1007/978-3-642-13914-7_2 
Goswami BN, Madhusoodanan MS, Neema CP, Sengupta D (2006) A physical mechanism for North Atlantic SST influence on the Indian summer monsoon. Geophys Res Lett. https://doi. org/10.1029/2005GL024803

Gutjahr O, Putrasahan D, Lohmann K, Jungclaus JH, von Storch J-S, Brüggemann N, Haak H, Stössel A (2019) Max Planck Institute Earth System Model (MPI-ESM1.2) for the High-Resolution Model Intercomparison Project (HighResMIP). Geosci Model Dev 12:3241-3281. https://doi.org/10.5194/gmd-12-3241-2019

Hajima T, Watanabe M, Yamamoto A, Tatebe H, Noguchi MA, Abe M, Ohgaito R, Ito A, Yamazaki D, Okajima H, Ito A, Takata K, Ogochi K, Watanabe S, Kawamiya M (2019) Description of the MIROC-ES2L Earth system model and evaluation of its climatebiogeochemical processes and feedbacks. Model Dev Discuss Geosci. https://doi.org/10.5194/gmd-2019-275 (in review)

Harris I, Jones PD, Osborn TJ, Lister DH (2014) Updated high-resolution grids of monthly climatic observations-the CRU TS3.10 Dataset. Int J Climatol. https://doi.org/10.1002/joc.3711

Haensler A, Saeed F, Jacob D (2013) Assessing the robustness of projected precipitation changes over Central Africa on the basis of a multitude of global and regional climate projections. Clim Chang 121:349-363

He B et al (2019) CAS FGOALS-f3-L model datasets for CMIP6 historical Atmospheric Model Inter-comparison Project simulation. Adv Atmos Sci 36(8):771-778. https://doi.org/10.1007/s0037 6-019-9027-8

Held IM, Guo H, Adcroft A, Dunne JP, Horowitz LW, Krasting J et al (2019) Structure and performance of GFDL's CM4.0 climate model. J Adv Model Earth Syst. https://doi.org/10.1029/2019m s001829

Hunt KMR, Turner AG, Shaffrey LC (2018) The evolution, seasonality and impacts of western disturbances. Q J R Meteorol Soc. https:// doi.org/10.1002/qj.3200

IPCC (2014) Climate change 2014: synthesis report. contribution of working groups I, II and III to the fifth assessment report of the Intergovernmental Panel on Climate Change. IPCC

Islam MN, Uyeda H (2007) Use of TRMM in determining the climatic characteristics of rainfall over Bangladesh. Remote Sens Environ. https://doi.org/10.1016/j.rse.2006.11.011

Islam MN, Das S, Uyeda H (2010) Calibration of TRMM derived rainfall over Nepal during 1998-2007. Open Atmos Sci J. https://doi. org/10.2174/1874282301004010012

Jayasankar CB, Surendran S, Rajendran K (2015) Robust signals of future projections of Indian summer monsoon rainfall by IPCC AR5 climate models: role of seasonal cycle and interannual variability. Geophys Res Lett. https://doi.org/10.1002/2015GL063659

Jena P, Azad S, Rajeevan MN (2016) CMIP5 projected changes in the annual cycle of Indian monsoon rainfall. Climate. https://doi. org/10.3390/cli4010014

Jones PW (1999) First- and second-order conservative remapping schemes for grids in spherical coordinates. Mon Weather Rev. https://doi.org/10.1175/1520-0493(1999)127\%3c2204:FASOC $\mathrm{R} \% 3 \mathrm{e} 2.0 . \mathrm{CO} ; 2$

Kamworapan S, Surussavadee C (2019) Evaluation of CMIP5 global climate models for simulating climatological temperature and precipitation for southeast Asia. Adv Meteorol. https://doi. org/10.1155/2019/1067365

Kitoh A (2017) The Asian monsoon and its future change in climate models: a review. J Meteorol Soc Jpn. https://doi.org/10.2151/ jmsj.2017-002

Kripalani RH, Kulkarni A, Sabade SS, Khandekar ML (2003) Indian Monsoon variability in a global warming scenario. Nat Hazards. https://doi.org/10.1023/A:1023695326825

Kripalani RH, Oh JH, Kulkarni A, Sabade SS, Chaudhari HS (2007) South Asian summer monsoon precipitation variability: coupled climate model simulations and projections under IPCC AR4. Theor Appl Climatol. https://doi.org/10.1007/s00704-006-0282-0

Krishnamurthy L, Krishnamurthy V (2014) Influence of PDO on South Asian summer monsoon and monsoon-ENSO relation. Clim Dyn. https://doi.org/10.1007/s00382-013-1856-z

Krishnan R, Sabin TP, Ayantika DC, Kitoh A, Sugi M, Murakami H et al (2013) Will the South Asian monsoon overturning circulation stabilize any further? Clim Dyn. https://doi.org/10.1007/ s00382-012-1317-0

Krishnan R, Shrestha AB, Ren G, Rajbhandari R, Saeed S, Sanjay J, Ren Y (2019) The Hindu Kush Himalaya assessment. https://doi. org/10.1007/978-3-319-92288-1

Kumar N, Yadav BP, Gahlot S, Singh M (2015) Winter frequency of western disturbances and precipitation indices over Himachal Pradesh, India: 1977-2007. Atmosfera 28(1):63-70. https://doi. org/10.20937/atm.2015.28.01.06

Lal R (2013) Food security in a changing climate. Ecohydrology and Hydrobiology. https://doi.org/10.1016/j.ecohyd.2013.03.006

Lauritzen PH, Nair RD, Herrington AR, Callaghan P, Goldhaber S, Dennis JM et al (2018) NCAR release of CAM-SE in CESM2.0: a reformulation of the spectral element dynamical core in dry-mass vertical coordinates with comprehensive treatment of condensates and energy. J Adv Model Earth Syst 10:1537-1570. https://doi. org/10.1029/2017MS001257

Law RM, Ziehn T, Matear RJ, Lenton A, Chamberlain MA, Stevens LE, Wang Y-P, Srbinovsky J, Bi D, Yan H, Vohralik PF (2017) The carbon cycle in the Australian Community Climate and Earth System Simulator (ACCESS-ESM1)-Part 1: model description and pre-industrial simulation. Geosci Model Dev 10:2567-2590. https://doi.org/10.5194/gmd-10-2567-2017

Li C, Yanai M (1996) The onset and interannual variability of the asian summer monsoon in relation to land-sea thermal contrast. J Clim. https://doi.org/10.1175/1520-0442(1996)009\%3c0358:TOAIV $\mathrm{O} \% 3 \mathrm{e} 2.0 . \mathrm{CO} ; 2$

Liu S-M, Chen Y-H, Rao J, Cao C, Li S-Y, Ma M-H, Wang Y-B (2019) Parallel comparison of major sudden stratospheric warming events in CESM1-WACCM and CESM2-WACCM. Atmosphere 10:679

Lu R, Dong B, Ding H (2006) Impact of the Atlantic multidecadal oscillation on the Asian summer monsoon. Geophys Res Lett. https://doi.org/10.1029/2006GL027655

Madhura RK, Krishnan R, Revadekar JV, Mujumdar M, Goswami BN (2014) Changes in western disturbances over the Western Himalayas in a warming environment. Clim Dyn. https://doi.org/10.1007/ s00382-014-2166-9

Massonnet F, Ménégoz M, Acosta M, Yepes-Arbós X, Exarchou E, Doblas-Reyes FJ (2020) Replicability of the EC-Earth3 Earth system model under a change in computing environment. Geosci Model Dev 13:1165-1178. https://doi.org/10.5194/ gmd-13-1165-2020

Mauritsen T, Bader J, Becker T, Behrens J, Bittner M, Brokopf R et al (2019) Developments in the MPI-M Earth System Model version 1.2 (MPI-ESM1.2) and its response to increasing $\mathrm{CO}_{2}$. J Adv Model Earth Syst 11:998-1038. https://doi.org/10.1029/2018M S001400

MoFE (2019) Climate change scenarios for Nepal for National Adaptation Plan (NAP). Ministry of Forests and Environment, Kathmandu, Nepal

Mujumdar M, Preethi B, Sabin TP, Ashok K, Saeed S, Pai DS, Krishnan R (2012) The Asian summer monsoon response to the La Niña event of 2010. Meteorol Appl 19(2):216-225. https://doi. org/10.1002/met.1301

NCHM (2019) Analysis of historical climate and climate projection for Bhutan. NCHM

O’Neill BC, Kriegler E, Ebi KL, Kemp-Benedict E et al (2016) The roads ahead: narratives for Shared Socioeconomic Pathways 
describing world futures in the 21 st century. Global Environ Change. https://doi.org/10.1016/j.gloenvcha.2015.01.004

Ogata T, Ueda H, Inoue T, Hayasaki M, Yoshida A, Watanabe S et al (2014) Projected future changes in the Asian monsoon: a comparison of CMIP3 and CMIP5 model results. J Meteorol Soc Jpn. https://doi.org/10.2151/jmsj.2014-302

Pathak R, Sahany S, Mishra SK, Dash SK (2019) Precipitation biases in CMIP5 models over the South Asian region. Sci Rep. https:// doi.org/10.1038/s41598-019-45907-4

Pattnayak KC, Kar SC, Dalal M, Pattnayak RK (2017) Projections of annual rainfall and surface temperature from CMIP5 models over the BIMSTEC countries. Glob Planet Change. https://doi. org/10.1016/j.gloplacha.2017.03.005

Rehman N, Adnan M, Ali S (2018) Assessment of CMIP5 climate models over south Asia and climate change projections over Pakistan under representative concentration pathways. Int J Glob Warm 16(4):381-415. https://doi.org/10.1504/IJGW.2018.095994

Riahi K, Vuuren DP, Kriegler E, Edmonds J, O’Neill BC, Fujimori S, Bauer N, Calvin K, Dellink R, Fricko O, Lutz W (2017) The shared socioeconomic pathways and their energy, land use, and greenhouse gas emissions implications: an overview. Global Environ Change 42:153-168. https://doi.org/10.1016/j.gloen vcha.2016.05.009

Rong XY, Li J, Chen HM et al (2019) Introduction of CAMS-CSM model and its participation in CMIP6. Clim Change Res 15(5):540544. https://doi.org/10.12006/j.issn.1673-1719.2019.186

Saeed F, Hagemann S, Jacob D (2009) Impact of irrigation on the South Asian summer monsoon. Geophys Res Lett. https://doi. org/10.1029/2009GL040625

Saeed S, Müller WA, Hagemann S, Jacob D (2011a) Circumglobal wave train and the summer monsoon over northwestern India and Pakistan: the explicit role of the surface heat low. Clim Dyn 37(5):1045-1060. https://doi.org/10.1007/s00382-010-0888-x

Saeed S, Müller WA, Hagemann S, Jacob D, Mujumdar M, Krishnan R (2011b) Precipitation variability over the South Asian monsoon heat low and associated teleconnections. Geophys Res Lett 38(8):1-5. https://doi.org/10.1029/2011GL046984

Saeed S, Brisson E, Demuzere M, Tabari H, Willems P, van Lipzig NPM (2017) Multidecadal convection permitting climate simulations over Belgium: sensitivity of future precipitation extremes. Atmos Sci Lett 18(1):29-36. https://doi.org/10.1002/asl.720

Séférian R, Nabat P, Michou M, Saint-Martin D, Voldoire A, Colin J et al (2019) Evaluation of CNRM Earth-System model, CNRMESM2-1: role of Earth system processes in present-day and future climate. J Adv Model Earth Syst. https://doi.org/10.1029/2019M S001791

Seland Ø, Bentsen M, Seland Graff L, Olivié D, Toniazzo T, Gjermundsen A, Debernard JB, Gupta AK, He Y, Kirkevåg A, Schwinger J, Tjiputra J, Schancke Aas K, Bethke I, Fan Y, Griesfeller J, Grini A, Guo C, Ilicak M, Hafsahl Karset IH, Landgren O, Liakka J, Onsum Moseid K, Nummelin A, Spensberger C, Tang H, Zhang Z, Heinze C, Iverson T, Schulz M (2020) The Norwegian Earth System Model, NorESM2-Evaluation of theCMIP6 DECK and historical simulations. Geosci Model Dev Discuss. https://doi.org/10.5194/gmd-2019-378 (in review)

Sellar A, Jones C, Mulcahy J, Tang Y, Yool A, Wiltshire A, O'Connor F, Stringer M, Hill R, Palmieri J, Woodward S, Mora L, Kuhlbrodt T, Rumbold S, Kelley D, Ellis R, Johnson C, Walton J, Abraham N, Andrews M, Andrews T, Archibald A, Berthou S, Burke E, Blockley E, Carslaw K, Dalvi M, Edwards J, Folberth G, Gedney N, Griffiths P, Harper A, Hendry M, Hewitt A, Johnson B, Jones A, Jones C, Keeble J, Liddicoat S, Morgenstern O, Parker R, Predoi V, Robertson E, Siahaan A, Smith R, Swaminathan R, Woodhouse M, Zeng G, Zerroukat M (2019) UKESM1: description and evaluation of the
UK Earth system model. J Adv Model Earth Syst. https://doi. org/10.1029/2019MS001739

Seth A, Rauscher SA, Biasutti M, Giannini A, Camargo SJ, Rojas M (2013) CMIP5 projected changes in the annual cycle of precipitation in monsoon regions. J Clim. https://doi.org/10.1175/JCLID-12-00726.1

Sharmila S, Joseph S, Sahai AK, Abhilash S, Chattopadhyay R (2015) Future projection of Indian summer monsoon variability under climate change scenario: an assessment from CMIP5 climate models. Glob Planet Change. https://doi.org/10.1016/j.glopl acha.2014.11.004

Singh D, Ghosh S, Roxy MK, McDermid S (2019) Indian summer monsoon: extreme events, historical changes, and role of anthropogenic forcings. Wiley Interdiscip Rev Clim Change 10:e571. https://doi.org/10.1002/wcc.571

Sivakumar MVK, Stefanski R (2010) Climate Change in South Asia. Clim Change Food Secur South Asia. https://doi. org/10.1007/978-90-481-9516-9_2

Solomon S, Qin D, Manning M, Chen Z (2007) Contribution of Working Group I to the Fourth Assessment Report of the Intergovernmental Panel on Climate Change

Song ZY, Ying BAO, Fang-Li QIAO (2019) Introduction of FIOESM v2.0 and its participation plan in CMIP6 experiments. Clim Change Res 15(5):558-565

Srivastava AK, Delsole T (2014) Robust forced response in South Asian summer monsoon in a future climate. J Clim. https://doi. org/10.1175/JCLI-D-13-00599.1

Swart NC, Cole JNS, Kharin VV, Lazare M, Scinocca JF, Gillett NP, Anstey J, Arora V, Christian JR, Hanna S, Jiao Y, Lee WG, Majaess F, Saenko OA, Seiler C, Seinen C, Shao A, Sigmond M, Solheim L, von Salzen K, Yang D, Winter B (2019) The Canadian Earth System Model version 5 (CanESM5.0.3). Geosci Model Dev 12:4823-4873. https://doi.org/10.5194/gmd-12-4823-2019

Tatebe H, Ogura T, Nitta T, Komuro Y, Ogochi K, Takemura T, Sudo K, Sekiguchi M, Abe M, Saito F, Chikira M, Watanabe S, Mori M, Hirota N, Kawatani Y, Mochizuki T, Yoshimura K, Takata K, O’ishi R, Yamazaki D, Suzuki T, Kurogi M, Kataoka T, Watanabe M, Kimoto M (2019) Description and basic evaluation of simulated mean state, internal variability, and climate sensitivity in MIROC6. Geosci Model Dev 12:2727-2765. https://doi. org/10.5194/gmd-12-2727-2019

Turner AG, Annamalai H (2012) Climate change and the South Asian summer monsoon. Nat Clim Change. https://doi.org/10.1038/ nclimate 1495

Voldoire A, Saint-Martin D, Sénési S, Decharme B, Alias A, Chevallier M et al (2019) Evaluation of CMIP6 DECK experiments with CNRM-CM6-1. J Adv Model Earth Syst 11:2177-2213. https:// doi.org/10.1029/2019MS001683

Volodin EM, Mortikov EV, Kostrykin SV, Galin VYa, Lykossov VN, Gritsun AS, Diansky NA, Gusev AV, Iakovlev NG, Shestakova AA, Emelina SV (2018) Simulation of the modern climate using the INM-CM48 climate model. Russ J Numer Anal Math Model 33(6):367-374. https://doi.org/10.1515/rnam-2018-0032

Woo S, Singh GP, Oh JH, Lee KM (2019) Projection of seasonal summer precipitation over Indian sub-continent with a high-resolution AGCM based on the RCP scenarios. Meteorol Atmos Phys. https ://doi.org/10.1007/s00703-018-0612-7

Wu G, Liu Y, He B, Bao Q, Duan A, Jin FF (2012) Thermal controls on the Asian summer monsoon. Sci Rep. https://doi.org/10.1038/ srep00404

Wu T, Lu Y, Fang Y, Xin X, Li L, Li W, Jie W, Zhang J, Liu Y, Zhang L, Zhang F, Zhang Y, Wu F, Li J, Chu M, Wang Z, Shi X, Liu X, Wei M, Huang A, Zhang Y, Liu X (2019) The Beijing Climate Center Climate System Model (BCC-CSM): the main progress from CMIP5 to CMIP6. Geosci Model Dev 12:1573-1600. https ://doi.org/10.5194/gmd-12-1573-2019 
Yukimoto S, Kawai H, Koshiro T, Oshima N, Yoshida K, Urakawa S, Tsujino H, Deushi M, Tanaka T, Hosaka M, Yabu S, Yoshimura H, Shindo E, Mizuta R, Obata A, Adachi Y, Ishii M (2019) The
Meteorological Research Institute Earth System Model version 2.0, MRI-ESM2.0: description and basic evaluation of the physical component. J Meteorol Soc Jpn. https://doi.org/10.2151/jmsj.2019-051 